I may add that I find the lead acetate process useful when a very rapid estimation has to be made in commercial whiskies concerning which there is no question of caramel coloration, but that, as a general rule, I employ the distillation process. It was by means of the latter that the series of figures relating to aldehydes and furfural in The Chemistry of Whiskey, Part II.,' by Kaye and the author were obtained.

57 Chancery Lane, London, W. C.

\title{
REVIEW.
}

\section{ABSTRACTS FROM CURRENT LITERATURE UPON INDUSTRIAL CHEMISTRY.}

By Frank H. Thorp.

Received December 24, I906.

In the present article, the same general scheme has been followed as in previous Reviews by the writer. But attention has been confined more closely than heretofore, to articles appearing in foreign journals. Since the more important Patents, at least, that are issued abroad, are generally re-issued in this country, it has seemed unnecessary, with a few exceptions, to include them here, as they will appear in the Abstract of Patents in connection with the Revieze of American Chemical Research. In the interest of brevity, some selection of subjects has been exercised, and only those which seemed of most general interest are included.

Technological Education:-The final report of the Departmental Committee appointed to examine the working of the Royal College of Science and School of Mines of Great Britain, was published in Feb., I906, and reprinted in the J. Chem. Ind., 25, (I906), 203. This embraces conclusions and recommendations embodied in some forty-two articles. It is concluded that advanced technological education must be provided; that such opportunity is not now fully available to students, owing to lack of facilities, absence of co-ordination among the several technological institutions of the country, whereby advanced courses could not be given in a few of them; and finally, that employers do not yet fully appreciate the value of such education for their employees. Opportunities for research in technological lines are inadequate. It is proposed to found at South Kensington, an Institution with staff and equipment which will attract advanced students. The body of the report is devoted to ways and means to give effect to this proposal. The scheme would include the work of the Royal College of Science, the Royal School of Mines, the Central Technical College, and additional departments to be established, wherein the highest specialized instruction and fullest equipment for advanced training and research in science, especially as applied to industry, would be given. The relation of this Institution to the University of London occupies a large part of the report, and the idea is advanced that the ulti-

${ }^{1} \mathrm{~J}$. Soc. Chem. Ind., June, 1905. 
mate union of the two should always be kept in view; but for the present it is proposed to put the new institution under a separate governing body. the membership of which is outlined. Some consideration is also given to the curriculum, especially with reference to the School of Mines, which is to include a two years' course of instruction, restricted to technical and advanced work in mining and metallurgy. Accommodations for one hundred and twenty students in this department, are proposed.

Acids:-Litmann ( $Z$. anger'. Chem.. I9, I039, I08I, (1906)), has studied the action of selenium in sulphuric acid making. It is thought that possibly a compound, $\mathrm{SeO}$, may be present. This perhaps dissolves in the strlphuric acid, forming a green solution; this may be a compound of stiphur dioxide or trioxide with selenium oxide, $\left(\mathrm{SeO} . \mathrm{SO}_{2}\right)$. On dilution the selenium is precipitated from solution, or, at high temperatures, selenimm dioxide may form.

$$
\begin{aligned}
& \mathrm{Se}+2 \mathrm{SO}_{3}=\mathrm{SeSO}_{2} \cdot \mathrm{SO}_{3} \\
& \mathrm{SeSO}+\mathrm{H}_{2} \mathrm{SO}_{4} \cdot \mathrm{H}_{2} \mathrm{O}=2 \mathrm{H}_{2} \mathrm{SO}_{4}+\mathrm{Se} \\
& \mathrm{SeSO}_{3} \cdot \mathrm{SO}_{3}=\mathrm{SeO}_{2}+2 \mathrm{SO}_{2} .
\end{aligned}
$$

The $\mathrm{SeO}$ or $\mathrm{SeSO}_{3}$ is volatile and is carried into the chambers with the burner gases. From weak acid the selenium can be precipitated by hydrogen sulphide.-The same author, (Ibid., II77), gives some of the data from a test of three chambers, under various conditions, as to introduction of the gases. In three trials, yields of $4.52,6.56$ and 7.48 kilos of 50 percent. acid per cubic meter, per 24 hours, with a niter consumption of 0.58 , 0.59 and 0.48 percent., were obtained. The author holds that the following reactions occur:

$$
\begin{aligned}
& \mathrm{NO}+\mathrm{SO}_{2}+\mathrm{O}+\mathrm{H}_{2} \mathrm{O}=\mathrm{OH} . \mathrm{NO} \cdot \mathrm{HSO}_{3} \\
& \mathrm{OH} . \mathrm{XO} \cdot \mathrm{HSO}_{2}+\mathrm{XH}_{2} \mathrm{O}=\mathrm{H}_{2} \mathrm{SO}_{4} \cdot \mathrm{XH}_{2} \mathrm{O}+\mathrm{NO}
\end{aligned}
$$

-Neumann (Chem.-Ztg., 30, 598, (I906)), discusses the reactions in the Glover tower and proposes a tower system for sulphuric acid making. In the tower, nitrosylsulphuric acid is produced exactly as in the ordinary lead chamber, but in the Glover, this acid is decomposed in the presence of much water vapor and sulphur dioxide, whereby three molecules of sulphuric acid are produced, with the same quantity of nitric oxide as forms only two molecules in the chambers. Since the reactions in the lower part of the Glover are endothermic with absorption of ( $\mathrm{n}$ ) calories of heat which is again evolved in the higher part of the tower, it is proposed to construct a series of towers arranged so that the gases entering at the bottom may be heated, while those leaving at the top, are cooled. The gases after passing through a tower, are sent through heaters placed in the flue for the burner gases passing to the towers. The burner gases are thus cooled to $160^{\circ}$ to $200^{\circ}$.

Wilke (J. Chem. Ind., 25, 4, (I906)), describes briefly the "Mannheim" Contact Process for making stiphuric acid. The contact material employed is the oxide of iron residue from pyrites burners, supplemented by a platinum contact mass, to complete the conversion of that part of the sulphurous acid, which has passed unconverted through the iron contact. The sulphur gases leave the kilns at about $700^{\circ}$, and are led through the iron contact at this temperature, where $50-60$ percent of the sulphur dioxide is converted to the trioxicle, while any arsenic in the gases com- 
bines with the iron to form arsenate. Since water in the gases reduces the catalytic activity of the iron oxide, the air supplied to the burners is dried by passing over sulphuric acid. The sulphur trioxide produced is then absorbed, and the sulphur dioxide remaining is converted by passing a platinum contact mass. To raise the gases to the necessary temperature for action in the platinum mass, a heater is so placed as to absorb the heat from the gases leaving the iron contact; but this is supplemented by a small coal fire. The platinum contact consists of platinized asbestos rets, which offer very little resistance to the passage of the gases. Conversion of the roaster gases, up to 75 percent, is claimed for the process. The plants are built in "units," of which a total number of 32 are built, or are now building in this country. -Delépine (Compt. rend., I4I, IOI3, (I905)), has studied the attack of concentrated sulphuric acid on platinum. In a closed flask at $338^{\circ}$, the platinum dissolved was about $0.0 \mathrm{gm}$. per sq. dcm. per hour. In open dishes solution is much slower owing to the lower temperature, due to evaporation. Acid potassium sulphate in the sulphuric acid, accelerates the solution considerably. Nitric acid in the sulphuric acid, up to O.I percent is found to have no marked effect on the solution, and the author holds that the attack of "commercial" concentrated acid is not due to the traces of nitric acid. Ammonium sulphate has a noticeable retarding effect and will even precipitate the platinum from its solution in sulphuric acid. The reaction between sulphuric acid and platinum is shown by the equation:-

$$
{ }_{4} \mathrm{H}_{2} \mathrm{SO}_{4}+\mathrm{Pt}=\mathrm{Pt}\left(\mathrm{SO}_{4}\right)_{2}+2 \mathrm{SO}_{2}+{ }_{4} \mathrm{H}_{2} \mathrm{O} \text {. }
$$

The same author (Ibid., I42, 63I, (I906)), states that platinum is dissolved by sulphuric acid to the extent of 2 grams in IOO cc. of the concentrated acid, if boiled for very long periods, e.g., 50 hours. Iridium increases the resistance of the platinum to solution somewhat, but the iridoplatinum is nevertheless dissolved.-Gmehling (Oesterr. Z. Berg. Hiitt., 54, 69, 88; Chem. Centr., I906, 1060), describes the roasting of copper matte at Guayacon, Chili. The sulphur dioxide fume is washed to remove dust, arsenic, copper, etc., and after drying, is utilized for sulphuric acid by the Schroeder-Grillo process. An output of 2250 kilos of 93 percent sulphuric acid per 24 hours, for each kilo of contact body used, is claimed. The matte averages 40-50 percent copper, 22-27 percent sulphur and 23-30 percent iron, with some silver and gold. The crude copper made runs about $97-98$ percent pure.-Lunge and Berl ( $Z$. angew. Chem., I9, $807,857,88 \mathrm{I}$, (I906)), contribute further papers upon the nitrogen oxides and the chamber process. (Compare this Journal, 28, 24I). Various contentions of Raschig are controverted and the authors' results summarized in some fifteen sections. -Nernst ( $Z$. anorg. Chem., 49, 213 , ( 1906$)$ ), has made a study of the formation of nitric oxide by the aid of electric sparks. The equilibrium concentration of nitric oxide varies with increase of temperature, being 0.10 at $1227^{\circ}$; 1.23 at $2027^{\circ}$; 2.44 at $2427^{\circ} ; 4.39$ at $2827^{\circ}$. The reaction is merely a thermal one, $\mathrm{N}_{2}+\mathrm{O}_{2}=2 \mathrm{NO}$. - Jellinek, (Ibid., 229), in a study of the reaction, $2 \mathrm{NO} \rightleftarrows \mathrm{N}_{2}+\mathrm{O}_{2}$, finds that nitric oxide begins to decompose at $67 \mathrm{c}^{\circ}$. -Klaudy (Z. Elektrochem., I2, 545, (I906)), discusses the yield and cost of making nitric acid by electric discharge through air. The figures are very favorable. 
Inglis ( $J$. Chem. Ind., 25, I49, (Ig06)), contributes another paper upon the loss of niter in the chamber process. (Compare this Journal, 27. 4I7). Assuming that the niter must be present, as nitric oxide, or nitrogen trioxide, or nitrogen peroxide, in the chambers, and that the loss occurs in the flue leading away from the Gay-Lussac tower, the question of how the loss occurs, might be solved by analysis of flue gases. But owing to the large proportion of nitrogen and oxygen and the complex side-reactions brought about by the sulphur dioxide present, reacting with the nitrogen peroxide, absorption of the nitrous gases is difficult and incomplete, and the analytical data obtained cannot be interpreted. Hence, the author proposed to attempt the analysis by fractionation of the gases at low temperatures. Using liquid air as refrigerant, a temperature of - I $89^{\circ}$, is obtained, and under these conditions, carbon dioxide, nitrons oxide, nitrogen trioxide, nitrogen peroxide, sulphur dioxide, sulphur trioxide and sulphurous acid. are all non-volatile solids, while nitrogen, oxygen and nitric oxide do not condense. A second fractionation at - $2^{\circ}{ }^{\circ}$ (obtained by melting solidified ether), separated the carbon dioxide and nitrous oxide as volatile substances. At $-95^{\circ}$, sulphur dioxide distills and nitrogen trioxide breaks up into nitric oxide and peroxide, the former distilling off ; these gases were then separated by fractionation at $-I 89^{\circ}$ again. Thus the five fractions obtained were. ( I), nitrogen, oxygen and nitric acid: (2), nitrous oxide and carbon dioxide: (3), nitric oxide from the trioxide; (4), stlphur dioxide; (5), nitrogen peroxide and sulphurous acicl. These were then analyzed. The special tube used for the fractionation is illustrated. After describing the diffculties encountered in the analytical work and giving the results in several tables, the author sums up as follows:-(I). Only very small quantities of nitrogen peroxide and trioxide are reduced to nitrotis oxide in the sulphuric acid chambers. (2) About so percent. of the total loss of niter takes place owing to incomplete absorption of the nitrogen peroxide and trioxide in the Gay-Lussac tower. In the discussion of the paper, the point was brought out that the author's results supported Prof. Lunge's contention as to the real cause of the niter loss in the chamber process.

Wolf, (Z. ges. Schiess-Sprengstoffw. I, 373. (1906)). describes the Skoglund apparatus for making nitric acid, with sketch of the apparatus. A horizontal cast-iron retort connects with an earthenware retort filled with quartz or other material not attacked by acid. From the top of the tower a tube passes to a lead cooling worm, and this connects with two or more towers, similar to the first, and which are especially intended to collect the $\mathrm{N}_{2} \mathrm{O}_{3}$ and $\mathrm{N}_{2} \mathrm{O}_{4}$ vapors. The charge is 1500 kilos of Chili saltpeter. The acid condensed in the worm and tower ranges from 45 to $49^{\circ}$ Bé., of which about 9 r. 5 percent is "strong acid" from 47 to $49^{\circ}$ Bé.Guttmann ( $I$ bid., 376 ), compares this process with his own and claims that the Skoglund apparatus yields only 94.75 percent. of the strong acid, while 5 percent. of weak and nearly unsalable mixture is produced; with the Guttmann apparatus, over 99 percent. of high strength acid results. He then calculates the value of the acid produced by the two methods, and for Iooo kilos of saltpeter used, estimates abont 13 percent. more for the product from the Guttmann apparatus.

Cement.-Blount, (J. Chem. Ind., 25, 1020, (1906)), reviews recent progress in the cement industry. The progress from the empirical mant- 
facture of 1886 , to that of scientific control as now practiced is very interestingly brought out. The investigations of Le Chatelier, the Newberrys, Richardson and others, upon the chemistry of cement, are well summed up. The experiments of Hurry and Seaman in attempting to produce cement by a blast furnace operation are cited as showing a probable future development. But as the fusion temperature is higher than that of the ordinary blast furnace, a modified form of apparatus, capable of being worked under pressure, is suggested. But difficulties are to be expected in accomplishing this. As alternative, it is suggested that oxygen may be added to the air employed in the blast. It is also proposed to devise an apparatus in which the charge could be brought to high temperature or incipient fusion by an air blast, and the process completed by electrical heating. The cost is held to be the greatest deterent of any such plan. But for simplicity of management, uniformity of product, and utilization of materials, the fusion process should offer many attractions. A very long discussion followed. -Maynard, (Thonind. Ztg., 30, 440), has experimented with cement poor in lime, to test its resistance to sea-water. Using slag cement, low in lime, very good results were obtained, but the test pieces must be kept immersed in sea water long enough for combination between the silica and lime to take place.

Cellulose.-Ost, ( $Z$. angew. Chem., I9, 993, ( I906)), finds that cellulose acetate has the same composition, $\mathrm{C}_{6} \mathrm{H}_{7} \mathrm{O}_{5}\left(\mathrm{C}_{2} \mathrm{H}_{8} \mathrm{O}_{2}\right)$, whether produced by the process of Cross and Bevan, of Bayer, or of Lederer; he disputes the claim of Cross and Bevan that a tetra-acetate is produced. He even doubts that a tri-acetate of normal cellulose exists, and inclines to the view that the substance is a tri-acetate of hydro-cellulose. He finds the reaction is progressive and if stopped at an intermediate stage, di-acetates may be separated; the reaction is entirely analogous to the nitration of cellulose, and reaches the maximum when three hydroxyl groups for each $\mathrm{C}_{8}$ molecule, have been substituted by the acetyl group.-Green and Perkin (J. Chem. Soc., 89, 8I I, (I906)), having investigated the supposed tetraacetate of cellulose, have come to the conclusion that it contains only three acetyl groups and hold that this would confirm Green's formula for cellulose :-

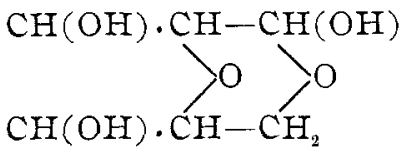

-Will (Z. angew. Chem., I9, (I906), I377), has made an experimental study of celluloid with reference to its stability against ignition or explosion. If made from carefully prepared nitrocellulose of high stability, the celluloid is comparatively safe from ignition or decomposition by shocks, blows, friction or heat to $100^{\circ}$; nor will electric sparks cause explosion. But poorly made nitrocellulose will form a product which will ignite under these conditions. A test of stability in celluloid is proposed: - o. I gm. cut into small bits, is heated in a test-tube in an oil bath, starting at $100^{\circ}$, and raising the temperature uniformly $5^{\circ}$ per minute. The temperature at which fumes of nitrogen oxides are evolved, is noted. Good samples should not fume off below $170^{\circ}$. Celluloid dust can be ignited by electric sparks. When burned, celluloid evolves carbon monoxide, hydrogen and methane, which cause explosion when mixed with air, and 
with scant air supply, some nitric oxide and hydrocyanic acid are formed. The poisonous nature of the gases should be kept in mind when attempting to extinguish such fires.

Brown, (Z. angew. Chem., I8, I976, (I905)), reports the results of tests made for the Ministry of Finance, St. Petersburg, by Gervais, on the inflammability of celluloid articles. At $100^{\circ}$, spontaneous decomposition takes place, after some time, which causes evolution of heat sufficient to cause blackening or smouldering of the wrapping paper; but ignition of the celluloid does not take place. The celluloid will not ignite unless in contact with a body already fully on fire. The ignition temperature ranges from $355^{\circ}$ to $457^{\circ}$.

Dyes and Dyeing.-Pilling, (J. Soc. Dyers Colorists, 22, 54, (1906)), has studied the cause of the weakening of the fibre of cottons dyed with sulphur blacks. This tendering is due in all cases to sulphuric acid, originating from decomposition of the color itself, or oxidation of sulphurous acid from outside sources, in which catlytic agents take part. Seven colors were dyed on yarn under the same conditions, and then the methods of fixing were varied:-(I), oxidation by exposure to air; (2), with potassium bichromate and acetic acid; (3), with copper sulphate; (4), with copper sulphate, bichromate and acetic acid; (5), with ferrous sulphate; (6) with chrome alum. A set of these yarns was then heated 24 hours at $100^{\circ}$; the others at $\mathrm{I} 10^{\circ}$, and $120^{\circ}$, and $130^{\circ}$, for 12 hours. The tensile strength of each, and amount of sulphuric acid contained, was then determined. In all cases, the fibre is weakened, and stlphuric acid formed. Moreover the method of fixing had an important part in the tendering; copper salts yielding the weakest fibre. A second series of yarns were stored at ordinary temperature for various periods of time, from six weeks to ten months. Again the copper treated yarns were weakest, while oxidation with bichromate and acetic acid had little tendering effect. The presence of sulphtiric acid is attributed to oxidation of the color molecule in those cases where the dry yarn has been directly subjected to heat; but when exposed to the air the presence of sulphurous acid becomes important. A series of tests in which the skeins were exposed to sulphurous acid and then dried in the air, showed much weakening of the fibre; while those skeins which were washed before drying, showed little loss of strength. Copper and iron salts accelerated this oxidation of sulphutous acid in the fiber, with consequent tendering of the goods.-Kertesz (Ibid., 93), asserts that the chrome-acetic acid after treatment does not prevent tendering of the fiber. But the injury can be prevented by using an alkaline bath for the final treatment of the goods.

Linder and Picton, (Trans. Chem. Soc., 87, Ig06, (1905)), have continued their study of solution and pseudo-solution, and in this paper, with special reference to the Theory of Dyeing. By adding ammonium sulphate to a colloidal ferric hydroxide solution, all the iron and sulphuric acid are precipitated; Soluble Blue, or Nicholson's blue act in the same way as ammonium sulphate. But basic dyes, such as methyl violet (which is a chloride), cause no coagulation, though it readily coagulates arsenious sulphide which is not coagulated by the acid dye. Hofmann's violet and magenta act like methyl violet. Thus the coagulation produced by the dyes is analogous to that of metallic salts. But by adding an excess of acid dye to ferric hydroxicle, it is taken up by the coagulum to an amount 
equal to four or five times that needed to produce coagulation before the excess of dye colors the solution. Basic dyes (methyl violet) are taken up in excess by arsenious sulphide; and in both cases the dye is absorbed as a whole. But basic dyes are not absorbed by ferric hydroxide, nor acid dyes by arsenious sulphide.-Dreaper, (this Journal, 28, 253), supports this colloidal theory of dyeing, and the authors seem to agree with him. To explain the absorption of dye by ferric hydroxide, the properties of the solutions are considered; they are coagulated by sodium chloride and the hydrogels are granular. They exhibit difference of potential between molecular aggregates and the fluid. The basic substances (methyl violet and ferric hydroxide) carry plus charges; the acid bodies (aniline blue and arsenious sulphide) carry a minus charge. Two oppositely charged hydrosols in dilute solution, unite and form a pseudo-solution; but in strong solution, they mutually coagulate each other. They show that the potential difference between the molecular aggregates and the hydrosol, is not all destroyed by the coagulation, but is merely reduced. They hold that "substantive dyeing" takes place in two stages:-in the first, an interchange between the colloidal fiber stubstance and the dye, results in precipitation of insoluble dye bodies having a slight electrical charge. In the second stage, the color is absorbed by the coagulum of the first stage, and retained, owing to its opposite charge.

Erban, (Chem.-Ztg., 30, I45, (Ig06)), describes the preparation of titanium hydroxide from rutile and its conversion into titanium-ammoniumoxalate, for mordanting and dyeing cotton and leather. Basic dyes applied on a tannin-titanium mordant, give fast colors which excel those obtained with tannin and antimony. -Brown, ( $J$. Soc. Dyers Colorists, 22; I I, (I906)), contributes an article on the Indanthrene series of dyes, the first of which appeared in I9OI, and has been followed by seven or eight others on various colors. The constitution of these complicated bodies is first considered and then the methods of application.-Bergtheil (Rep. Agri. Dep't. of Land Records, Bengal). Through (J. Soc. Dyers Colorists, 22, 100, (1906)), has given an account of the investigations on indigo, which are being conducted in India with a view to improving the quality and yield of the product. The work was begun by Mr. C. Rawson in I 898 and has been continued since by various investigators. Improvements in the plant are most promising, new varieties carrying a higher content of indigo having been introduced. Also fertilization of the soil has been studied; and material improvements made in the process of manufacture. Attempts are being made to cultivate nodule bacteria peculiar to indigo, on lines similar to those proposed by Dr. Moore of the U. S. Dept. of Agriculture.-Vidal and Junius, (French Pat. 359,093), propose to dye wool and animal fibers with certain sulphide blacks (especially those from p-amino-phenol or substituted diphenylamines, and sulphur) which are soluble in alkali sulphide liquors to which acetic acid has been added. These solutions are yellow in color and the goods develop blue shades by oxidation in the air.-A red sulphur dye to which is ascribed the formula, $\mathrm{C}_{6} \mathrm{H}_{4}\left\langle\begin{array}{c}\mathrm{CO} \\ \mathrm{S}\end{array}\right\rangle \mathrm{C}=\mathrm{C}\left\langle\begin{array}{c}\mathrm{CO} \\ \mathrm{S}\end{array}\right\rangle \mathrm{C}_{6} \mathrm{H}_{4}$, and which is derived from thioindoxyl has been patented in France, (Nos. 359,398, 359,399 and $359,400)$ The dye has appeared in commerce as Thioindigo red $\mathrm{B}$, and 
is fast to light and chlorine.-Knecht, ( $J$. Soc. Dyors Colorists, 22, 156, (I906)), describes the preparation and uses of this dye and finds it more easily reduced than indigo, but the reduced "leuco" substance is less reaclily oxidized than indigo.

Prudhomme, (Rev. gen. mat. color., Io, I, (1906)), has studied the products obtained from hydroxy-anthraquinones. Alizarin, reduced with zinc and hydrochloric acid, yielded a brown body which dyes mordanted material from neutral bath, producing shades similar to the alizarin itself: from acid baths, only weak dyeing resulted. By further reduction, this body yielded a green substance, which in turn produced, with acid, a yellow material, similar in appearance to alizarin, while hydrogen escapes. By oxidation, this gave a violet color. Formulae for the three bodies are proposed. Anthrapurpurin, by reduction, yields two colored bodies, similar to those obtained from alizarin. Flavopurpurin. on reduction, forms products which dye very similarly to alizarin itself.-In a Frenci patent (No. 356,569), taken by the Deutsche Gold-u-Silber-Scheide Anstalt, it is proposed to make lenco derivatives of indigo, by heating caustic soda-potash mixture with metallic sodium and salts of phenylglycine, to about $200^{\circ}$, in a vessel from which the air is excluded.König. ( $J$. pr. (hem., 72, 555. ( tgo:)), finds that when furfural (I mol.), is heated with an alcoholic solution of an aromatic anine ( 2 mols), and, after cooling, an acid ( $\mathrm{m} \mathrm{mol}$ ), is added, pure crystals of dyestuff separate, which are capable of dyeing unmordanted vegetable fibers.Hibbert, ( $J$. Soc, Dyers Colorists, 22, 276, (Igo6)), has compared the sodium "hydrosulphite" with titanous chloride, for bleaching and stripping old color from fabrics which are to be re-dyed. On cotton, dyed with Benzopurpurin 4B, and with Chrysophenin, the titanous chloride gave much better results. But there is some deposition on the fiber of titanic oxide or hydroxide, and this may give trouble when the goods are to be mordanted with tannic acid, owing to the production of an orange color. This deposition of titanic hychoxicle may be overcome by adding potassium oxalate to the titanous chloride solution. The double titanicpotassium oxalate is not subject to hydrolytic decomposition.

Cain and Norman (Chem. Soc. Trans., 89, I9, (I906)), have found that hydroxy compounds of the ortho-substituted diazonitum salts of benzenes, can be produced by diazotizing, and decomposing the diazo body with sulphuric acid at temperatures above $135^{\circ}$. - d Andiran ( $B \mathrm{mll}$. soc. ind. Mulhouse, 75, 385, ( 1905 )), has produced a soluble brown dye by treating isohematein sulphate (made by dissolving hematein in sulphuric acid), which is very slightly soluble, with sodium bistrlphate and sodium acetate. This isohematein brown is suggested as valuable for calico printing. It is fast to light and soap, and can be printed on heavy pile goods without bleeding. By a similar procedure, isobrasilein sulphate can be made to yield a dye which produces a claret when printed with chromium mordant. -Biltz and Utescher, $(B c r ., 38,4$ I 43, (I905)), have examined certain color lakes, with a view to cletermining whether they are true chemical compounds, or merely adsorption compounds. With iron oxide and alizarin dissolved in caustic soda, a body corresponding to $\mathrm{Fe}_{2} \mathrm{O}_{2 .} \cdot 3 \mathrm{C}_{14} \mathrm{H}_{4} \mathrm{O}_{4}$ was formed in the cold solution. But with boiling solutions, chromium hydroxide produced only adsorption compounds, as dicl other alizarins with iron and aluminum oxides. No definite result was obtained. Other 
dyes in alcoholic solution with iron oxide showed such variations in the quantity of color combined with the iron, that no stoïchiometrical formula could be applied. -Gulinow, (Z. Farb. Ind., 5, 337, (Igo6)), has proposed a new scheme of analysis and identification of artificial dyestuffs, based upon reduction of the dyestuff with zinc dust or stannous chloride. A tabular view of the procedures is given.

Bergtheil and Briggs, (J. Soc. Chem. Ind., 25, 729, ( I906)), have made a careful study and comparison of the various methods of determining indigotin in the commercial indigo, and in indigo plants. The conclusions are reached that analytical methods depending upon the extractive action of solvents are unreliable and valueless. The same is true of methods involving reduction of the indigo, with subsequent re-oxidation of the indigotin, and of methods wherein the indigotin is sublimed. When the indigo is sulphonated, with subsequent oxidation of the indigotin-disulphonic acid, only those methods employing potassium permanganate, are reliable, and among these, Rawson's is given the preference. Several methods based on the reduction of the sulphonated indigo, in which the indigotin-disulphonic acid is reduced to the leuco-compound by titration with a reducing substance, such as sodium hyposulphite or titanous chloride, were tested. These worked well with pure indigotin, but in commercial samples containing impurities, the end points were not clear and sharp. For such indigos, Grossmann's method of purification (Ibid, 24, 308), must be employed.-Bloxam (Ibid, 25, 735), also publishes a long investigation of indigo analyses. It is concluded that the method in which indigotin is separated as potassium tetrasulphonate, from the solution of sulphonated indigo, by the use of potassium acetate, is most accurate. It may be applied to pure indigos and to the crude article in process of manufacture.

Mordants:-Schellens (Arch. Pharm., 243, 6I7, (1905)), has studied the fixation of metallic salts from solution by vegetable and animal fibers. By maceration in the salt solution for some days, followed by washing and boiling in water until no test for either acid or base was obtained in the liquor, the author found that more or less of the base was always retained in the fiber. Iron, lead, mercury, iodine, and chromium compounds all yielded appreciable quantities of the base to the fiber. Potassium nitrate and chromic acid were more or less reduced, and the latter deposited chromium trioxide on the fiber.

Printing:-Wilhelm (Bull. soc. ind. Mulhouse, 76, $84 ; J$. Chem. Ind., 25, 69I, (I906)), has discovered new methods of producing discharge pat. terns by means of "hydrosulphite" compounds upon a-naphthylamine claret. Dry hydrosulphite (B. A. S. F.), ground in glycerol and thickened with dextrin, is used to produce white or colored discharges. Sodium hydrosulphite-formaldehyde (hydrosulphite N. F.) printed with certain dyestuffs which seem to have a "catalytic" action, gives excellent discharges. Numerous formulas for colored and white discharges are given.

Electrochemistry: Haber and Goldschmidt, ( $Z$. Elektrochem., I2, 49, (I906)), have investigated the electrolysis of iron pipes. The corrosion alters the structure of the iron, which becomes a soft, porous mass, consisting of iron particles, mixed with carbon, ferrous phosphate and silicate. This change is charged to the electric railroads, the pipes near the power stations being attacked owing to current leakage into the earth. 
Local corrosion is thought to be due to unusually high conductivity in the soil at these points. If chlorides, carbonates, or carbonic acid are present in the soil, corrosion is more likely to occur. Alkaline carbonate solution furnishes free carbonic acid at the anode, and this forms bi-carbonate, which is very corrosive on iron. But in the absence of salts in the soil, no serious corrosion need be feared, if the potential difference between the rails and pipes is less than one volt.

The fixation of atmospheric nitrogen now seems to be established on a tolerably firm commercial basis. Plants are now in operation in Norway (producing nitrates by the arc discharge in air) and in Italy (producing calcium cyanamide). Papers on these processes have been read by Birkeland (Proc. Faraday Soc., I906), by Frank, (International Congress for Applied Chem., I906), and by Guye, (Chem. Ind., 29, 85, (Igo6)). Guye states that the union of oxygen and nitrogen at the electric arc temperature, produces nitric oxide, but when cooled to $600^{\circ}$, the last takes up more oxygen to form nitrogen peroxide. The reaction, $\mathrm{N}_{2}+\mathrm{O}_{2} \rightarrow 2 \mathrm{NO}$, is reversible, and very high temperatures, followed by rapid cooling, are essential to a good yield. The author estimates that 500 kilos of nitric acid can be made per kilowattyear at a cost of 12 francs per roo kilos of nitric acid. Acid made from niter costs about 35 francs per Ioo kilos. It is suggested that the manufacture of calcium cyanamide be combined with that of nitric acid, since the oxygen for the liquid air, used in the former, would be available for mixing with the air t1sed for the nitric acid process, with increased yield of acid.--Extended reviews of these processes were recently given by Pennock. (this Jotrnal, 28, I242, (1906)).

Guye ( $J$. Soc. Chem. Ind., 25, 567, (1906)), contributes an exhaustive article upon the Electro-chemical Fixation of Nitrogen. After showing the importance of the question, there is a detailed discussion of the industrially important processes. The cyanamide process of Frank and Caro is studied as to the cost of the calcium carbide, of the nitrogen and of transforming the carbide into cyanamide. The net cost of the cyanamide is estimated at $3 \mathrm{I} 5$ francs per ton, equal to $\mathrm{I}$ s., $3 \frac{\mathrm{I} / 2}{\mathrm{~d}} \mathrm{~d}$., per kilo for the nitrogen contained, which is about the same as for nitrate or ammoniacal nitrogen. But the cyananide is only 0.64 to 0.95 as efficient as Chili saltpeter, hence the actual cost is much higher than above figured. Concerning nitric acid produced from air, there are again, three factors: - the initial reaction, the temperature influence, and the reverse reaction. The initial reaction is always incomplete and for any given condition of pressure, temperature and composition, the reaction stops when the nitric oxide amounts to a certain value. The higher the temperature the further the reaction goes and also, the more rapidly is the equilibrium condition reached, while the cost of the greater expenditure of energy for the high temperature, is more than offset by the better efficiency. The reverse reaction, in which the nitric oxide dissociates into nitrogen and oxygen, takes place during the cooling process; hence it is well to cool the gases rapidly. The cost of the nitric acid is estimated at 255 frs. per ton, or I I $1 / 2$ d., per kilo of nitrogen. As to future prospects, it is shown that waterpower for the necessary production of electrical energy in Europe, amounts to about one million kilowatts, which is not sufficient to produce the total amount of nitrates and ammonia salts consumed, hence econon- 
ical power must be sought in gas motors utilizing low grade coal. Mond's gas producers, which yield ammonia as a by-product, are to be the means of obtaining cheap power and also of increasing the supply of ammonium salts. An extended discussion by Pres. Divers, Sir William Ramsey, Dr. Caro, Dr. Voelcker and several others, adds much information upon the nitrogen supply.

Guye (Fr. Pat., No. 360,435), has devised a method of working electrolytic diaphragm cells in a "cascade system." The cathode compartments of several cells are joined so that liquor flows through each in succession. The current density being so adjusted that it decreases in each succeeding cell in proportion to the increase of caustic in the solution. The anode compartments may or may not be joined in a similar series.Findlay ( $Z$. Elektrochem., I2, I29, (I906)), reports the formation of hydrogen peroxide by the passage of a Tesla brush discharge through water vapor, although Nernst (Ibid., II, 7IO), failed to detect it in a similar experiment.-Müller and Bahntje (Ibid., I2, 317, (I906)), have studied the electrolytic deposition of copper from solutions containing small amounts of colloidal substances, e. g., albumin, gelatin and gum. Gelatin had the most noticeable effect, producing brilliant amorphous deposits, in acid solution. The colloid is supposed to prevent the metal from assuming a crystalline character.-Wallach (Ibid., 12, 667, (I906)), describes a continuous process for the electrolytic production of potassium chlorate. About $0.2 \mathrm{~g}$. of potassium bichromate per IOO cc., of the electrolyte was added, and the electrolysis carried on at $70^{\circ}$. Current yields from 85 to 92 percent. of theoretical were obtained, and the product was practically pure.-Betts has proposed to use metallic sodium encased in copper or other metal as electrical conductor. (Fr. Pat. No. 361,102). Sodium has only one-ninth the specific gravity of copper, but its electrical conductivity is one-third that of copper; so the claim is made that a sodium conductor will carry as much current as a copper wire weighing three times as much. But some increase of risk from fire and difficulties from moisture would seem inevitable with such material.

Explosives.-Thompson (Report of Chiet Insp. of Explosives) after investigating an explosion of nitrogylcerol in a drum of spent acid at Abbey Mills, traced the cause to separation of the nitroglycerol from solution in the acid, owing to cooling to low temperature. The acid had been diluted with 3 percent. water before shipment, but at least 5 percent. water is recommended for this dilution, if the temperature is liable to fall.Volpert (Chem.-Ztg., 30, Rep., 215. (I906)), gives a description of dinitroglycerol and advocates it as a safe explosive. It does not congeal when chilled, can be mixed with ammonium nitrate, and does not make much smoke on explosion.-Sieder, (Chem. Centrb., rgo6, I, 1905), describes an explosive, "oxyliquit," consisting of liquid air, nixed with oxidizable substances, as wood charcoal. Liquid oxygen may be used instead of liquid air.-Silberrad and Simpson (Chem. Soc. Proc., 22, I72, (Igo6)), have made an analysis of some ancient gunpowder, supposed to have been made about I64I, found in Durham Castle. The ingredients found were, potassium nitrate, $74.8 \mathrm{I}$, percent, carbon $\mathrm{I} 4.87$ percent, and sulphur I0.09 percent, which corresponds closely with a modern powder. But the ingredients had merely been mixed, and no thorough incorporation, nor granulation had been attempted. The calorimetric value and pressure 
recorded, agree well with the figures for modern powder.-Roewer, (Chem.-Ztg., 30, Rep., 240, (I906)), proposes nitrated monochlorhydrin as an admixture to nitroglycerol explosives. It is easily prepared and is a good solvent for trinitroglycerol and greatly lowers the freezing point of the latter, when added in proportion of 5 to 10 percent. It also reduces the sensitiveness to shocks. On detonation it liberates hydrochloric acid, but this may be in part obviated by mixing alkali nitrates in the explosive.

Saposhnikow (Z. ges. Schiess.-Sprengstoffic., I, 69, (I906)), gives the composition of various powders used by the Japanese. The "smokeless" for field guns is composed of 40 percent. soluble pyroxylin, with 60 percent, of insoluble nitrated cellulose. The former contains i I percent. nitrogen and the latter I 3.4 percent. "Shimose" is practically the same as melinite. - Lunge (Ibid., 393) describes the improved method of making nitroglycerol used at Waltham Abbey, England. A sketch of the apparatus is given. The acid mixture 3 parts nitric and 5 parts sulphuric acid, is run into the nitration apparatus through the same pipe by which the nitrated product is drawn off. Air for cooling and stirring may be introduced through a perforated coil in the bottom of the tank. Aiter nitrating the mixture stands in the same tank until cooled somewhat and separation has taken place. Then, spent acid from previous nitrations is carefully run in from below, without mixing with the nitroglycerol; the latter rises to the overflow, and runs off clear, until the line of separation between acid and nitroglycerol appears at the overflow. Then a little of the spent acid is drawn off, till the level of the liquid drops below the overflow; about 2 percent. of water, (calculated on the weight of the spent acid), is then introduced, and mixed by blowing air. After a further settling and removal of the separated nitroglycerol, the spent acid is drawn off and no further separation of nitroglycerol from the acid will take place.

Robertson, (J.Chem. Ind., 25, 624, (Ig06)), reports upon the washing and purifying of gun-cotton after nitration. Experiments on a large scale were tried at the Royal Gunpowder Factory, in which the nitrated cotton was boiled (a), in water alone; (b), in catustic liquors; (c), with alkaline carbonates. It is concluded that the impurities are more rapidly eliminated and the stability of the product improved by boiling with dilute acid at the beginning of the process of washing. And this boiling should be of considerable duration, - I2 hours has been found satisfactory. About I percent. of acid (as $\mathrm{H}_{2} \mathrm{SO}_{4}$ ), calculated on the weight of the gun-cotton, should be present in the first wash-water. The boiling in water carrying calcium carbonate in suspension, after the acid boiling; should not be too prolonged, as this results in some decomposition of the gun-cotton. Boiling in any alkaline liquid caused considerable hydrolysis of the nitrated cotton. The periods of boiling with change of water recommended are $\mathrm{I} 2+\mathrm{I} 2+4+4+4+4+4+2+2+2$ hours, with intermediate washing with cold water.

Silberrad and Farmer, (Ibid., 96r), has studied the deterioration of nitrocellulose in storage. Large quantities of nitrocellulose powders were stored in zinc lined chambers of considerable size, where the temperature could be kept at any desired point for long times. Each chamber was inclosed in non-conducting material and the whole put into a corrugated iron building, a little larger than the magazine itself. Some chambers were heated by steam-coils, others chilled to $-18^{\circ}$. The atmosphere within 
the chambers was in nost cases kept dry, but in a few instances the air was kept saturated with moisture. The temperatures were regulated by thermostats and kept within $\pm I^{\circ}$ from the mean, at all times. There is considerable variation in the same lot of powder, and this was eliminated by fastening a number of sticks together in a bundle, which was retained through the whole experiment, and at desired intervals of time, samples for analysis were taken by sawing across the end of the bundle, thus cutting a small piece from each stick. The changes on storing were classified as, (I), Physical alterations;-Odor, due to nitrogen peroxide, and in ether-alcohol powders, to ethyl nitrite; attack on packing materials due to the nitrogen peroxide weakening and bleaching the silk, or oiled paper wrappers; appearance, alteration through shrinkage in dry atmosphere, or to development of stickiness and softening of the sticks in moist air. (2), Chemical changes;-Loss of weight, due to decomposition of nitric esters; Loss of nitrogen by decomposition of nitrate and evolution of nitrogen oxides; increase of ether-alcohol, soluble nitro-cellulose, and decrease of the "insoluble" variety; increase in acetone-soluble constituents; increase of water soluble extract; Decrease in the heat test; $(3)$, Acceleration of decomposition by the auto-catalytic action of the products of decomposition. (4), Influence of moisture is shown to be very great in determining the velocity and nature of the decomposition. When hydrolysis of the constituents occurs, the powder becomes more difficult to ignite and may ultimately lose all its explosive character. (5), Influence of temperature is very marked, and at higher heats the velocity of decomposition is doubled by each raise of $5^{\circ}$. Hence in hot climates, frequent tests are necessary; at $104^{\circ}$, the decomposition is sixteen times as rapid as at $68^{\circ} \mathrm{F}$. Most powders are stable indefinitely at $60^{\circ}$.

A bulletin from the laboratory of the Dynamit-Aktien Gesellschaft, Nobel and Co., Hamburg, appears (Mon. sci., 20, 595, (I906)), in which the results of comparative tests of a number of explosives, are given. The heat evolved, the temperature of the explosion, the volume of the gases evolved, the expansion of a standard Trauzel cylinder and the ratio of this expansion as compared to that produced by gelatin dynamite, are all determined and tabulated, for ten different samples.Noble (Roy. Soc. Trans., 206, 453, (I906)); (J. Soc. Chem. Ind., 25, IOO3, (I906)), has continued a series of researches on explosives. The subject is treated mathematically and is accompanied by several curve charts showing explosion temperatures, pressures per square inch, and volume of gases evolved.-Cooper-Key, in a report upon an explosion in a powder mill induced by lightning, (J.SOc. Chem. Ind., 25, 1067, (Ig06)), describes the "cage" system of lightning conductors recommended for protection against this form of accident.

Fats and Oils:-Rahn, (Chem.-Ztg., 30, (1906) (Rep.), 30), finds that certain micro-organisms have the power of decomposing fats, even when very little nitrogen is present. Cultures of varieties of Pencillium, of certain mould fungi, and two varieties of bacteria were made. The Pencillium was found to decompose the glycerol and some fat acids. The mould fungi had but little effect, while one of the bacilli also exerted hydrolytic action and even decomposed oleic acid.-Thomson and Dunlop ( $J$. Soc. Chem. Ind., 25, 272, (I906)), show that the refractive index of cod-liver oil is valueless as a test for purity or oxidation of the oil. The constants 
of fresh seal oil are given and the conclusion is reached that seal oil pres. ent in cod-liver oil cannot be detected by analytical methods.-Wielezynski (Chem.-Ztg., 30, I06, (I906)), gives analyses of samples of crude petroleum from Boryslaw. This oil seems to vary in the different wells, and even in the same well. Generally the benzene fraction is small, and the heavy paraffins predominate in the oils.-Charitschkow, (Chom.-Ztg., 30 . $(R e p), 35$.$) , has tried bleaching Baku petroleum residues with potassium$ dichromate and sulphuric acid, followed by washing with caustic soda. Clear but dark brown oils were thus obtained.-Fokin (Chem. Rev. Fett. 14. Harz-Ind., 13, 130, 163, I92, 219, 238, (1906)) ; J. Soc. Chem. Ind., 25. 999, (I906)), contributes a long series of articles on the hydrolysis of fats by enzymes. It is concluded that no connection exists between the nature of the fat, and the presence of lipolytic enzymes. Plants containing such enzymes, are so far as known, of poisonous character, but many seeds containing alkaloids are unable to hydrolyze fat. The hydrolysis induced by the seeds of Chelidonium majus, and of castor seeds, was carefully studied.

Fermentation:-Franzl (Hantkes Letters on Brewing, 5, 223, (I906)), advocates paraffined wooden fermentation vats for beer. No woody taste is imparted to the beer, nor is there any noticeable action on the paraffin. - Henneberg, ( $Z$. Spiritusind., 29, 34, (I906)), has found that formic acid is suitable for disinfecting in distilleries and for yeasts. With yeasts about $0.17-0.25$ percent. of formic acid prevented the growth of any organism aside from the yeast. But the organisms were not killed and could still develop if brouglit into a suitable medium. The author (Ibid., 93), has studied the temperatures necessary for sterilizing the mash in distilleries and yeast factories. The organisms which cause the most trouble are Mycoderma, and lactic and acetic bacteria. These can be killed by heating the mash to $55^{\circ}$, for a quarter of an hour. This does not injure the diastase. Failure of the method in sterilizing mashes on a large scale may occur through portions of the mash being splashed on the sides of the vat, and so not receiving the full heat. - Hansen, (Centr. Bakt. Parasitenk., I905, I5; Wochschr. Brante., 23, 220), has investigated the change of type in yeast. Starting with a bottom-fermentation yeast, Saccharomyces turbidans, by growing and keeping in a shallow layer of wort at a low temperature, $0.5^{\circ}$, for some months and then making new cultures from the product, the author produced strongly characterized top-fermentation yeast. The original yeast was found to contain both top- and bottom-fermentation cells, and at the low temperature only the former were capable of reproduction, thus increasing largely the proportion of this kind of yeast cells. Other experiments of similar character, showed that $S$. Johannisber $\sigma$ II, a bottom yeast, and $S$. validus, a top yeast, behave in the same way. There is no evidence of direct change of type in any species. Fränkel and Hamburg, (Wochschr. Brauw., 23, 473, (I906)) ; (I. Chem. Ind., 25, 945, (1906)), have prepared pure diastase by growing a pure culture of Frohberg yeast in a malt extract which had been purified by basic lead acetate and filtered through a sterilized Pukal filter. After the fermentation is finished, the liquid is again filtered and evaporated under vacuum to a small volume. Any acidity is removed with calcium carbonate and the liquicl again fermented with a nixtme of Frohberg and 
Logos yeasts, and again filtered and concentrated in racuo to a thick syrup. This was then dried in vacuo, over sulphuric acid and yielded a light yellow powder which was free from albumin, and from fermentable or reducing carbohydrates. This is very soluble in water but not in alcohol. It does not show the biuret reaction, nor reduce Fehling's solution. Its pure aqueous solution can be completely precipitated by colloidal ferric hydroxide, but the precipitate has no diastatic power. Other colloids do not precipitate it from solution, and this is held to be an argument against the colloidal character of diastase. Passage of an electric current through the solution does not cause migration to either anode or cathode; but the ultramicroscope shows bi-concave pencils of light in the solution, which point to the presence of minute particles and hence to a colloidal character of the diastase. -Breaudat, (Compt. rend., I42, I280, (I906)), has cliscovered a new aerobic bacterium in a water from Cochin-China, which has the power of forming acetone in solutions containing peptones and sugars. It liquefies gelatin, curdles milk and reduces nitrates. The name Bacillus violarius acetonicus, was given. - Aliaire, (Ibid., I43, I76, (1906)), has made an ultimate analysis of bacterial masses collected from a Jiquid which has undergone acetic fermentation. The alcohol extract amounted to 1.56 percent. and consisted largely of lecithin. The residue, after extraction yielded 6.9 percent. nitrogen and 5.9 percent. of mineral ash, mainly composed of phosphates and oxicles of iron, calcium, magnesium, sodium and potassium, with a little copper and silica. The proportion of iron and copper is considered significant in the process of the acetic fermentation.-Schidrowitz and Kaye, (J. Inst. Brew., I2, 450, I906) ), have subjected waste yeast to destructive distillation and obtained ammoniacal liquor ( 25 percent.), tar ( 7.6 percent.), gas and coke (48.8 percent.). Ammoniacal liquor contained 6 percent. of ammonia and the gas also contained much, which could be recovered by scrubbing. The tar was similar to that from bone distillation and also contained 4.8 percent. of ammonia. The total yield of ammonia was $58 \mathrm{lbs}$, per ton of dry yeast. By treating the yeast with sulphuric acid and drying down with some chalk added, a dry mass containing 8 to 9 percent. of ammonia and suitable for fertilizer, is obtained.-Mann ( $J$. Chem. Ind., 25, 1o76, ( 1906$)$ ), calls attention to a possible source of alcohol in the core of the stem of Xanthorrhoea preissii or "grass tree" of Australia. This contains fermentable sugars, and tests show that I.24.gals. proof spirit could be made from 60 pounds (one bushel), of the core meal. This is about the same yield of alcohol as from potatoes.-Buchner and Meisenheimer, (Ber., 39, 320I, (I906)), have continuted their studies on alcoholic fermentation with expressed yeast-cell juice (This Journal, 28, 26I). They have found that glycerol is produced in the fermentation, but succinic acid is not. Some of the sugar was converted into a polysaccharide through reversion by an enzyme, and some is consumed in the formation of the glycerol. Very little fusel oil was found in the alcohol. The same authors have investigated the formation of lactic acid (Ann., 349, I25, (I906)). A wort made from barley and rye malt, was sown with cultures of $B$. Delbriicki; the bacteria were collected and dried and extracted with acetone and ether. Sterile preparations containing active enzymes were obtained, and used for starting fermentations in sugar solutions. It ferments cane-sugar and maltose, but apparently hydrolysis of the sugars 
is first induced by enzymes causing inversion. The dried enzymes made inactive lactic acid, but the living bacteria form levorotary lactic acid.Buchner and Gaunt (Ibid., I40), prepared the dried enzymes from acetic bacteria in a similar manner to the above process. These were collected in flasks upon a mixture of alcohol, chalk and toluene. The action of the bacteria is attributed to an oxidizing enzyme.

Breaing:-A committee appointed by the Council of the Institute of Brewing to investigate methods for the analysis of malt, has made a report to the Council (J. Inst. Breci.. I2. I, ( 1906$)$ ), giving standard methods. The article does not permit of satisfactory short abstractions.Schnegg, (Z. ges. Bralci., 28, 807, 820, (I905)), having carefully tested formaldehyde for clisinfecting, finds it very satisfactory $A$ o.5 percent. solution is userl; the pipes, vats, walls, etc., having been first thoronghly scrubbed, are then soaked for several hours with the liquid. One application weeliy is advocated and no injury to the rubber, wood or metal work is observed. - Weber, (Wochschr. Brantw, 23, 95, (Igo6)), advocates the use of fermentation vats made with wired glass sides and bottom, bedded in cement, and the joints covered with brewers' pitch. He claims slightly better results in the fermentation and more economy in the saving of space and smaller cooling plant.

Distillation:-Schidrowitz and Kaye (J. Inst. Brew., I2, 486, (1906)), have studied "pot-still" whiskey distillation as practiced in Scotland, particularly with reference to the distribution of the impurities among the several products. There is collected from the wash distillation, a single fraction, called "low wines," and containing all the alcoholic bodies, while "pot ale" is left in the still as residumm. The "low wines" are redistilled and separated into "foreshots," "whiskey" and "feints," while "spent lees" remain in the still. "Foreshots" and "feints" are returned to the still with the next lot of low wines. It is found that the impurities are largely elininated in the spent lees, and somewhat in the pot ale; but they concentrate in the foreshots and in the feints, hence are returned, as above stated.

Fertiliser:-Hall and Norrison, (Proc. Roy. Soc., 77, 455, (1906); J. Chem. Ind., 25, 598), have found that silica assists in the nutrition of cereal plants, especially those which contain a considerable amount of silica in their ash. The addition of sodium silicate solution caused earlier formation of grain (barley) and larger yield. This is attributed to the stimulus given to the plant. making possible increased assimulation of phosphoric acid from the soil.

Foods:-Weil, (Eng. Pat., No. 15,667 of 1905), has proposed to coat tartaric acid crystals with paraffin before mixing with sodium bicarbonate and starch for baking powders. Thus the action of the acid is retarded. -Fleurent, (Compt. rond., I42, 180. (Igo6)), advances the view that only nitrogen peroxide is of value for bleaching flour. Ozone has little or no action on the sellow color and imparts an acid character to the flour. The yellow oil of the flour is not oxidized by nitrogen peroxicle, but a combination of the two occurs and the resulting product is colorless. The iodine ralue of the oil is thus decreased, hence the keeping qualities of the flour is impaired. Pleached flour can be detected by extracting the oil with petrolem ether, dissolving it in amyl alcohol and 
treating with alcoholic potash. Bleached flour containing nitrogen oxides, becomes orange-red by this treatment.

Fine Chemicals:-Garelli, ( $Z$. angerw. Chem., 19, 895, (1906)), in a paper before the Sixth International Congress of Applied Chemistry, at Rome, proposed the decomposition of monazite sand for thorium and cerium, by fusing with sodium peroxide, or with sodium and potassium chlorates. The fused mass is decomposed with sulphuric acid and the two rare earths precipitated from the solution by adding ammonia, and heating; the precipitate is extracted with oxalic acid, and the thorium and cerium separated with sodium thiosulphate, or salicylic acid. Ceric salts are suggested as oxidizers for bleaching wool and for purifying acetylene. -Galimard and Verdier, (J. pharm. chim., 23, I83, (1906)); J. Soc. Chem. Ind., 25, 233), report the presence of arsenic in so-called pure glycerol, but that it is in a form not readily reduced by the ordinary Marsh test. Only after long boiling with dilute sulphuric acid in a return cooler, is the arsenical impurity capable of reduction in the Marsh apparatus.-Mannish, (Ber. pharm. Ges., I906, 57), has found phenacetin adulterated with $p$-chloracetanilide to the amount of 18 percent. The melting point of the adulterated sample was II $9^{\circ}-\mathrm{I} 20^{\circ}$.- - Howard, ( $J$. Soc. Chem. Ind., 25, 97, (I906)), gives an interesting account of the cultivation of cinchona bark in India and Java. By cultivation, the percentage of alkaloid in the bark has been increased to three or four times as much as the wild bark supplied.--Parry, (Chem. Druggist, 69, 230, (I906)), comments upon the adulteration of Otto of Rose. When distilled in the ordinary way, as practiced in the East, the specific gravity never exceeds 0.855 , nor is less than 0.850 . Vacuum distillation yields a product containing phenylethyl alcohol, but the gravity is higher than by the usual method. A high gravity without the presence of phenylethyl alcohol is usually an indication of adulteration with geraniol or other oil. -Werner von Bolton, ( $Z$. angewe. Chem., 36, I537, (1906)), reviews his work upon vanadium and niobium, and describes the properties of tantalum. The metal was first reduced by electrolysis of the tetroxide under high vacuum; but by electrolyzing the double fluoride of tantalum and potassium, the metal is obtained as a powder, which is fused in a vacuum, while the oxides vaporize. It is very ductile and is easily drawn into fine wires or rolled into sheets. If forged at a red heat, it is rendered very hard, but still retains its toughness. It melts about $2300^{\circ}$, has a specific gravity of about I6.5 to I6.64, and its coefficient of linear expansion is 0.0000079 , between $0^{\circ}$ and $50^{\circ}$. It is not readily oxidized in the air when heated, but a thin scale of pentoxide coats the surface. It combines with carbon, but is rendered hard and brittle if about one percent. is present. With iron it forms a very hard alloy; and it also combines with sulphur, selenium, tellurium, tungsten, molybdenum and nitrogen, but not with silver or mercury. Mineral acids, except hydrofluoric, and caustic alkaline solutions have no action upon it, but fused alkali attacks it.Orlow, (Chem.-Ztg., 30, 733, ( I906)), proposes to purify cerium salts by employing the soluble ceric oxalate produced in the presence of excess of ammonium oxalate. Impure cerium compounds, or oxides are dissolved in sulphuric acid by heating, the solution diluted, and poured into a large excess of ammonium oxalate; the solution is at once filtered rapidly. The orange colored filtrate may contain the oxalates of thorium and cerium, 
but the oxalates of other metals are left in the residue. On standing, the filtrate becomes colorless, owing to reduction of the ceric salt, and a precipitate of cerous oxalate separates, which is free from thorium, since the latter remains soluble. The reduction is hastened if sodium sulphite be added to the solution.-Velardi (Chem. Centr., I906, I030), finds that bitter almonds can be rendered non-poisonous by heating the kernels to $I 70^{\circ}$., at which temperature the amygdalin can no longer develop hydrocyanic acid. -Böhm, (Chem. Ind., 29, 450, 488, (1906)), reviews the thorium industry in two lengthy articles. The method of decomposing monazite, the concentration and purification of the thorium oxide and manufacture and testing the thorium nitrate, are fully discussed. The commercial uses of the rare earths separated in the purification of the thoria, are also considered. Considerable space is devoted to a discussion of the speculative combination of manufacturers of thorium preparations, and their relation to the makers of incandescent mantles.

Fuel:-Lewis, (J. Gas Lighting, 94, 33, (I906)), contends that oxidation of pyrites in coal is a subordinate factor in causing spontaneous combustion. The chief cause is surface condensation of oxygen in the pores of the coal, and in consequence of this, a tendency of the hydrocarbons of the coal to be oxidized also. Thorough wetting of the coal is considered impracticable, owing to the large quantity of water needed and consequent great increase in weight of the storage bins. It is proposed that small cylinders of liquid carbon dioxide, sealed with fusible metal, be buried in the coal bins when filled. In case of fire, the heat fuses the plug and allows the carbon dioxide to escape through the mass. This produces local chilling and smothers the fire by the heavy gas.-Beilby, in an adclress to the Glasgow University Eng. Soc., (J. Soc. Chem. Ind., 25, 2 II, (I906)), advocates gas engines and steam turbines for reducing coal consumption and conserving the national coal resources. The anntial horsepower production in Great Britain by boiler and engine is estimated at $5,000,000$ with coal consumption of $50,000,000$ tons; a change to gas engines and turbines would reduce this to $\tau 2,000,000$ tons. Mond producergas or steam turbines, should produce power in England as cheaply as is now obtained by water in other countries. - Constam and Rougeot, $(Z$. angew. Chem., 10, I706. (I006)), have compared the result obtained by Parr's method for calorific values of coal, with those by the Mahler bomb. The variations may amount to 3 percent. of the total value, and complete combustion of the coal was not attained in any case with the Parr apparatus and the authors do not regard it as sufficiently reliable.

Gas and Illumination:-White and Clary, (J. Gas Lighting, 92, 388, 466, (I905)), have studied the absorption of naphthalene from coal gas, by hot tar. It is concluded that nearly all the naphthalene in the gas is absorbed by hot tar in the hydraulic mains and the standpipes, provided the gas remains in contact with the hot tar for a sufficient length of time; cold tar, however, absorbs much less. The phenols in the tar are presumed to be solvents for the naphthalene, and if any of the tar carrying naphthalene comes into the scrubber, the ammonia will dissolve the phenol and liberate the naphthalene, which then may be carried upwards by the gas. This is supposed to be the explanation of the presence of the naphthalene in the mains. (See also White, C. A., I.)-Colman, (Ibid., 526, 596 and $672)$, criticizes the above and claims that there is no proof that there is less 
naphthalene in the gas after treatment with hot tar, than before. Also the conclusions drawn above are contrary to the known facts of practice.Young, (Ibid., 742), also criticizes the above paper, and makes the point that naphthalene is taken up by coal gas the more readily the higher the temperature, and the rate of absorption is more rapid than is the case with tar, hence the power of the tar to absorb the naphthalene from gas is really less when hot than when cold.-Vogel, $(Z$. anyez. Chem., I9, 49, (I906)), reviews the present status of acetylene and the carbide industry in Germany. That acetylene is making progress is evident from the fact that some I 3 million gallons of petroleum for lighting purposes, were, presumably, replaced by the 24,000 tons of carbide consumed in that country last year. The price of carbide averaged 22 marks per Ioo kilos and about 290 liters of acetylene are obtained per kilo. Germany is not favorably situated for manufacturing carbide, and nearly three-fourths of the consumption was imported.-Sienens and Halske (Eng. Pat. No. 23,097 and 23,098), propose to draw metallic tantalum as fine wire, upon which brittle metals, such as tungsten, osmium, etc., can be deposited, to produce mantles or filaments for incandescent lamps.-Taubert, (Compt. rend., 142, 788, (Igo6)), proposes to make metallic calcitum by the electrolysis of fused calcium chloride and then ignite it in an atmosphere of hydrogen to produce calcium hydride. The latter is proposed as a source of hydrogen by its reaction with water.-Bone and Andrew (J.Chem. Soc. 89, 652, (1906)), have studied the effect of moisture upon the rate of oxidation of hydrocarbons by oxygen. Well dried mixtures of hydrocarbon and oxygen when heated, in comparison with undried mixtures of the same ingredients, showed that the moisture has no particular effect on the oxidation.-Bone and Drugman, (Ibid. 660), have examined the explosive combustion of hydrocarbons, in which there is actual propagation of flame through the mixture. With oxygen present in sufficient amount to form carbon monoxide from the hydrocarbon, the olefins or other unsaturated hydrocarbons decompose according to the reaction, $\mathrm{C}_{\mathrm{n}} \mathrm{H}_{2 \mathrm{n}}+\mathrm{O}_{2}=\mathrm{nCO}$ $-\mathrm{nH}_{2}$. Thus no carbon separates and no water is formed to any amount. But with a saturated hydrocarbon aqueous vapor is alwavs produced and more or less carbon separates as such, while other products, e. g., methane, carbon dioxide, carbon monoxide and hydrogen are also formed. Reducing the oxygen, however, causes an olefin to produce water, and also carbon. Acetylene, under these circumstances, produces no water. The authors discard the theory of preferential combustion of the carbon and hold the oxygen acts directly without necessarily involving the presence of any water vapor.-Liebenthal, ( . Gas Lighting, 95, I02, (Ig06)), reports the results of a comparative study of the photometric intensity of light of the Hefner, Harcourt and Carcel lamps, as made at the Charlottenburg Phys.-techn. Institute. A Io-candle pentane lamp, under certain standard conditions, gives a light equal to II Hefner units under the same conditions. The humidity of the air has some considerable effect on the results; an increase of aqueous vapor in the air decreases the illuminating effect of the pentane lamp, and also of the Hefner lamp. The Carcel lamp, with similar conditions of humidity, had an illuminating. power equal to Io.8 Hefner units, but with much fluctuation of light.Ross and Leather, (Analyst, 3I, 284, (I906)), have made an extended study of the composition of hydrocarbon oils for gas making. They draw the following conclusions from their work:-That open-chain compounds 
are most valuable for gas making; unsaturated bodies are less useful, while ring structure compounds are much less desirable. Oils, to be suitable for "cracking" should not contain benzene rings. The relation between specific gravity and refractive index was carefully studied and the constant for specific refraction of open chain oils, lies between 0.555 and 0.560 . This factor is reduced by hexamethylene or saturated double rings, but increased by unsaturated rings.

Glass:-Hoffmann, (Z, angew. Chom., I9, I089, (I906)), has examined the blue, vitreous mass obtained by fusing borax, boric anhydride and sodium sulphide together. A fusion of borax, sodium sulphide and phosphoric anhydride, or alum, also yields a blue glass. This "boron ultramarine" is stable, but is slightly soluble in water. It dissolves in hydrochloric acid with evolution of hydrogen sulphide. A sulphide is present, but no thiosulphate. The substance begins to form at about $720^{\circ}$ but is slowly decomposed by long heating at a high temperature, and the color clisappears, owing to loss of the sulphur. The body is similar to ordinary ultramarine, but boron here replaces aluminum. The sulphur is probably present as sodium sulphide.- A new process of glass working is reported by the $Z$. S. Vice-Consul at Nuremberg, Germany. The plastic glass is drawn up directly from the pot, between several pairs of smooth rolls which are placed in a frame over the pot. The thickness of the plate is guaged by the space between the rolls. The method is expected to affect the plate-glass manufacture in the near future.

Metallurgy:-Nenmann, (Z. Electrochen., I2, 569, (I906)), states that the lead peroxide anoles, proposed by Andreoli for precipitating gold from cyanide solution, are unsatisfactory because the cyanide attacks the metallic lead under the peroxide; but graphite electrodes withstand the cyanicle solution. It is also found that the cathode coated with the deposited gold, may be used directly as an anode in refining the gold in an acid solution of gold chloride, as in Wohlwill's process. Thus the trouble of recovering the gold from the lead cathodes, is avoided.-Jassoneix (Compt. rend., I43, I 69, ( I 906$)$ ), has obtained compounds of nolybdenum and boron by fusing these substances together in the electric furnace and using crucibles of pure magnesia. Alloys containing from 20 to 45 percent. boron, were thus made. $\mathrm{Up}$ to 20 percent. boron, the substances were hard and some even scratch quartz; higher amounts of boron redtce the hardness and change the metallic appearance to that of a slate like body. The substances are inert towards halogen acids, but hot, concentrated sulphuric and nitric acids dissolve them.-Ryss and Bogonolny (Z. Elektrochen., 12, 697, (1906)), have found that the best conditions for depositing metallic iron from ferrous chloride or ferrous anmonium sulphate solutions, are met if the solution contains $200 \mathrm{gms}$. of the salt per liter, with $50 \mathrm{gms}$. magnesium sulphate and $5 \mathrm{gms}$. of sodium bicarbonate: a current density of 0.3 amperes per sc. $\mathrm{dm}$, and a temperature of about $60^{\circ}$.- Hönigschmid (Compt. rend., I42, 280, (I906)), has made silicicle of thorium, 'ThSi $\mathrm{S}_{2}$, by heating thorium oxide in vacuo at $1000^{\circ}$ with silicon and aluminum. Likewise, by reducing thoria with aluminum, an alloy, $\mathrm{Th}_{3}$, which has the luster of aluminum, is produced. It does not oxidize in the air unless heated to a red heat, but is dissolved by acids and fused alkalies; alkaline solutions do not act upon it. -Dunstan, Jowett and Goulding, ( $J$. Chem. Soc., 
87 , I 548, (1905)), having studied the rusting of iron, conclude that the oxidation is caused by oxygen and water, without the aid of carbon dioxide or salts, although there is ground to suppose that hydrogen peroxide may be produced temporarily at least. - Divers, (Chem. Soc. Proc., 2I, 25I, (1905)), criticizes the above views and holds that hydrogen peroxide is not necessarily produced. -Moody, (J. Chem. Soc., 89, 720, (Ig06)), has failed to confirm the views of Dunstan, Jowett and Goulding, that carbonic acid is of minor consequence in the rusting of iron. He finds it has a marked influence on the rusting, and if completely excluded, no action takes place between the iron and oxygen in the presence of water. Neither does he find evidence of the formation of hydrogen peroxide as a necessary prelude to the rusting. Evidence of the presence of ferrous iron in the rust is shown and it is stated that the corrosive action of carbonic acid in water upon iron, in the presence of air, is greater in proportion to the weight of acid involved, than is that of hydrochloric or sulphuric acids. Hydrogen peroxide in dilute solution and free from acid, decomposes in presence of iron with evolution of oxygen gas, but no formation of iron oxide. -Smith, (J. Chem. Ind., 25, 29I, ( I906)), describes the effect of vanadium on steel. A number of samples of chrome-vanadium steel were examined microscopically and by various physical tests. Several micrographs at 350 diameters are shown and also a tabulation of the results of various tests.-Richter, (Chem.-Ztg., 30, 329, (Ig06)), having studied the causes of several explosions in the aluminum-bronze industry, attributes them to electric sparks from the brushes of the polishing machines and elevators. It is proposed to substitute aluminum wire brushes for the horse-hair and swine bristles commonly used in these elevators; and the brushes of the polishing machines should be grounded by fine copper wires; or by treating them with dilute sulphuric acid, a sufficient absorption of the acid occurs to impart conductivity properties to the bristles, whereby the electricity is diffused.-Edelmann, (Chem.-Ztg., 30, 925, 95I), finds aluminum powder is a good conductor for high voltages, as also are the brushes of the polishing mills: He doubts that sparking can occur in the mill; the electricity developed on the outer casing is generated by friction of the driving belt. The acidification of the brushes is condemned as useless and even dangerous, as hydrogen might be evolved and increase the risk.Moissan and Hönigschmid, (Monatsh, 27, 685, (1906)), have succeeded in preparing a small amount of metallic thorium, free from oxide, after a laborious series of experiments. The metal had never been obtained free from oxide previously. By heating the purified metal containing 5.I percent of oxide, in a carbon crucible, lined with thoria, in an electric furnace, a few small beads of fused thorium, free from oxide, were obtained. Stockmeier, (Chem.-Ztg., 30, 580, ( I906)), states that explosions of aluminum-bronze powders in the sifting and polishing processes, are merely dust explosions due to sparks from the machines. But there may be some hydrogen evolved by the action of water with the fine aluminum, when washing out any gum. This evolution of hydrogen may begin at temperatures near $30^{\circ}$, but not lower. But if water be thrown on large masses of hot aluminum powder, heavy explosions may follow. The use 
of exhanster fans has reduced the number of explosions in recent years. Frictional electricity may be the cause, but no authentic case is on record. - Arrivant, (Compt. rend., I43, 464, (I906)), has made alloys of manganese and molybdenum, using the aluminothermic process. The alloys were silver-white, hard and brittle, not altered by exposure to air, and nonmagnetic. They dissolve in hot sulphuric and in nitric acids, and partially in hydrochloric acid. The compounds $\mathrm{Mn}_{2} \mathrm{Mo}$. MnMo, and $\mathrm{MnMO}_{2}$, were identified as present in the alloys, with excess of metallic manganese. -Hiorns, (J. Soc. Chem. Ind., 25, 50, (Ig06)), has studied the effect of silicon, manganese, phosphorus and sulphur upon cast-iron. The article is illustrated with eleven photonicrographs of cast-iron, with these substances added. From the observations, it is concluded that with highly carburized iron, if the cooling be sufficiently slow, the iron being kept above $1050^{\circ}$, practically all of the carbon separates as graphite. Silicon appears to have no effect upon the separation of graphite, nor to prevent the carbon remaining in the combined form. The separation of graphite appears to be a function of the temperature and time only. Manganese appears to unite with the carbon, forming a double carbide of iron and manganese, if sulphur and silicon are absent. With silicon present, the manganese unites with it and thus neutralizes any possible effect of the silicon on the separation of graphite. Phosphorus in cast-iron lowers the percentage of total carbon, the decrease being proportional to the increase of the phosphorus percent. Its influence is, indirectly at least, towards the formation of combined carbon. Sulphur exists in cast-iton as readily fusible iron sulphide, which decomposes at high temperatures and evolves a gaseous compound as the metal slowly cools. This escape of the sulphur leaves the metal with a spongy texture. With manganese present, the sulphur is held as manganese sulphicle, and thus blow-holes in the iron are avoided. The stuphur, however, appears to cause the carbon to assume the combined form and prevent the separation of graphite. In the discussion following the paper, Buchanan made the point that hardening was directly attained by phosphorus, independently of the carbon; further, phosphoric iron never had a high sulphur content. Findlay advanced the view that the Roozeboom curves would apply to the conditions when manganese was present, but they only represent metastable systems; but the assumption that martensite and cementite formed the stable system, was wrong. The author agreed with this and also repeated his views that iron plus graphite was the stable condition of cast-iron and represented true equilibrium. - Hiorns, (Ibid., 25, 616, (1906)), also contributes an exhaustive paper accompanied with numerous photo-micrographs upon the effect of small amounts of arsenic, antimony, phosphorus, bismuth and lead, on the structure and properties of copper. With less than one percent. of these, the freezing point is lowered in every case, being greatest with phosphorus and least with lead; the latter forms no compound with copper; the lowering of the freezing point appears to be proportional to the intensity of the chemical affinity between the elements and the copper. There appears to be no compound of bismuth with copper, and the former separates as small globules between the copper crystals as the cooling proceeds, thus enclosing the copper crystals with a brittle envelope, which reduces the malleability of the mass. Lead acts in the same way, to some extent. 
Arsenic, antimony and phosphorus combine chemically with the copper; phosphorus does not change the malleability but does increase the hardness of the copper. Arsenic reduces the malleability very slightly, and antimony somewhat more. In commercial copper, cuprous oxide is present, and the first action of the element added is deoxidation of this substance, and only such amount of the element used in excess of this reaction is available for action on the copper. In the discussion of the paper, Rosenhain questioned some of the results as based on insufficient data; e. g., the copper arsenic alloy is referred to as a compound, but shows heterogeneous structure under the microscope. Also, there is doubt that a solid solution would crystallize at the lowest point of a freezing point curve, and then change to a eutectic on slow cooling.-Stansbie, (Ibid., 45), has studied the infuence of other elements in copper, upon its reactions with nitric acid. Observations were made upon the variations in the volume and composition of the gases evolved from copper, in which various elements were introduced. Variations in the temperature of the reaction were studied, and it appeared that the volume of nitric oxide liberated was larger, and of other gases less, as the temperature was higher. The concentration of the solution affected the quantity of nitrogen peroxide, which was produced in greater amount as the acid strength exceeded a definite amount. The acid strength was then kept at I.2 sp. gr. and the temperature at $65^{\circ}$. With one gram of pure copper the volume of nitric oxide liberated was found to average $176 \mathrm{cc}$., which was adopted as the standard volume. The volume calculated from the equation was $234 \mathrm{cc}$. and the difference is attributed to absorption of nitric oxide by the copper nitrate solution. Arsenic, antimony and bismuth, when alloyed in small amounts with the copper, modify the reaction between the metal and nitric acid. With all three, a decrease of nitric oxide evolved, was noted, which with arsenic and antimony, was most noticeable at 0.50 percent. of the impurity; with higher percentage of impurity, the volume of gas evolved increased. In the case of bismuth, there was decrease of the volume of nitric oxide liberated in all trials up to 2.5 percent. of bismuth present. Simple mixtures of copper filings with arsenic or antimony particles appeared to have no effect on the volume of nitric oxide evolved. In a second paper, (Ibid. IO7I), the influence of small quantities of elements in copper, upon its reactions with nitric acid, is studied. Only bismuth, arsenic and antimony were introduced as impurities in the copper. In the case of arsenic and antimony, the amount of nitrous acid produced, decreases at first, and then increases again, following the same general law as the decrease and increase of nitric oxide liberated, as the percentage of arsenic increases. With bismuth, a reverse action is noted:-an increase, at first, followed by a decrease of both nitrous acid and nitric oxide produced. It appears that the percentage of impurity having greatest effect, is that which gives the most perfect solid solution of the resulting alloy, in the excess of copper. The rate of action between the acid and copper is mainly influenced by the temperature, and concentration of the acid:- the temperature affects the distribution of the gas between the solution and the atmosphere above it. The formation of ammonia in the reaction is also a function of the temperature, being less at higher temperatures.

Pulp; Paper:-Krause, (Chem. Ind., 29, 2I7, (rgo6)), has examined the constituents of the waste liquors from sulphite pulp making, both by 
the Mitscherlich and Ritter-Kellner methods of boiling. The anount of sugar present in liquors produced in the Autumn was nearly twice that in liquor made in the Spring. The sugars present consist of xylose, galactose, levulose, mannose and dextrose. Besides these, there were identified, furfural, pentoses and pentosans. - Vogel, (Papierstg., 3I, i 278, I3I4, I355, (I906)). contributes some observations on the effituents from paper and pulp mills. The former are not considered especially troublesome, if the suspended matter is all removed. They contain organic soluble matter from the rag or straw boilers, but this is diluted by the water from the paper nuachines and is rendered less noxions by the bleaching liquors, hence may be discharged into large streams without causing nuisance. But spent sulphite pulp liquor contains hexose sugars besides the sulphites. The sugars nourish certain fungi when discharged into streams, while the sulphur compounds prevent any successful bacteriai treatment in septic tanks. By previous precipitation of the sulphites, the spent liquors could probably be subjected to septic putrefaction along with sewage. Continuous settling appliances have not proved so useful for removal of suspended matter from these liquors, as intermittent settling tanks. Waste soda liquors cause some growth of alga in small streams, but may be treated by the septic tank method, whereby the suspended matter is also removed.

Pigments:-Bronn, (Chem. Ind., 29, 105, 140, (1906)), comments upon the precaution to be taken to prevent lead poisoning in using or handling materials containing lead pigments. Enamels containing lead are to be applied to cast-iron in Dormoy's apparatus, which is a box with glass sicles and the bottom filled with rollers so placed that the hot casting rests securely upon them. The enamel powder is automatically shaken over the casting from a sieve, while the box is tightly closecl. Several analyses of glazes unattacked by boiling acetic acid, are given. Experiments looking to the substitution of zinc-white for white lead in paint, are quoted. Zinc-white needs more oil than white lead and its drying may be hastened by adding turpentine and manganese resinate. Zinc and tung oil have recently replaced red lead in making steam-tight joints on pipes.-Aschan and Ahlstrom, (Ber., 39, I44 I, (I906)), have fractionated American and French turpentine oil and examined the fractions distilled between $I 53^{\circ}$ and $175^{\circ}$. From the optical rotation and density of the fractions, it is conclucled that pseudo-pinene and other turpenes are present in the pinene fraction. Also cymene or limonene may be present. Aschan, (Ibid., I 44), has also investigated Finnish crude turpentine.-Valenta, (Chem.-Ztg., 30, 90I, (I906)), has tested the fastness to light of the pigment lakes made from coal-tar colors. Most of the pigments were made by precipitating the dye on barium, aluminum or tin bases. The colors have been tabulated in the order of their relative fastness.

Clay; Pottery:-Franchet, (Compt. rend., I4I, IO20, (1905)), describes a method for obtaining an iridescent metallic luster on ceramic articles. A glaze is prepared of quartz I 2; kaolin, 2 ; pegmatite, I 2.5; sand, 20 ; red lead, 30 ; borax, I9.2; boric acid, 2; sodium chloride, I.8; and potassium carbonate, 2. The mass is ground fine, fritted and granulated in water and again ground fine. To this glaze mixture, various metallic salts or oxides are added, before it is applied in the ordinary way. The ware is heated in a muffle until the glaze is fused, and then cooled slowly; at a 
dull red, smoke from wood, oil, or resinous material, or coal gas, or the gases from the combustion of sugar, are introduced into the muffle, and in the reducing atmosphere thus formed, the colored effect is soon produced. Silver yields tints varying from white to gold; copper and bismuth together give a pearly blue effect. Zinc and tin oxides are also used.Wagstaffe, (J. Soc. Chem. Ind., 25, IOI, ( Ig06)), reports upon the chemical and physical characteristics of some clays and shales from East Cheshire for brick making. The loss of weight and shrinkage when heated, the melting points of the clays, and the specific gravity and porosity of the briquettes, were the chief points determined.-Fleming (Ibid., 25, 680 , (I906)), describes the methods of firing potters kilns. Gas firing is only economical in large plants, as the production of gas must be continuous. Some difficulty has been found in controlling the gas consumption in the combustion chamber; the heat is too fierce in one section and too low in another. -Moore, (Trans. Eng. Ceram. Soc., 5, 37), has studied the possible causes of certain brown stains which sometimes appear in ware subjected to enameling. These stains usually appear in ware having a greenish tint after the glost fire, and the author holds that this is due to ferrous phosphate, which changes to the ferric salt when again heated.

Photography:-Farrell, (J. Soc. Dyers Colorists, 22, 24, ( I906)), states that silk, treated with nitrous acid in the cold, becomes sensitive to light owing to the diazonium substances produced, and by development with aromatic amines or hydroxyl compounds, after exposure to sunlight under a negative, photographs may be printed on the fabric. The diazotizing is produced by soaking the silk for several hours in a 0.5 percent. sodium nitrite, acidified with hydrochloric acid. After rinsing off, the goods are dried with tension in a dark place. By development with $a$ - or $\beta$-naphthol, resorcinol, etc., in the presence of sodium potassium hydroxide, various shades of bluish red, scarlet, or orange are obtained in those parts of the fabric which have not been altered by the light. By treating the diazotized silk with a hot water solution of a-naphthylamine, an azo body is formed, which can be again diazotized and developed with other amino compounds, producing other hues and shades.

Sheppard, (J. Chem. Soc., 89, 530, (I906)), contributes to the theory of development in alkaline solution, and a study of the relative reducing powers of the several agents. Hydroxylamine of moderate strength, reduced silver salt, molecule for molecule, but at high dilution the reduction is in the proportion of $I: 2$. Nitrogen is produced in the former and nitrous oxide in the latter case. Hydrogen peroxide reduces the silver salt according to the equation: $2 \mathrm{H}_{2} \mathrm{O}_{2}+\mathrm{Ag}_{2} \mathrm{O}=2 \mathrm{Ag}+\mathrm{H}_{2} \mathrm{O}$ $+2 \mathrm{O}_{2}+\mathrm{H}_{2}$. A table of the relative reducing powers, velocity of development, and concentration of bromide producing the same retarding effect as N/IOo bromide with ferrous oxalate, is given.

Rubber:-Herbst, (Ber., 39, 523, (I906)), passed dry air through a solution of Para rubber in benzene for I 40 hours. A little resinous matter of yellowish color separated, which was insoluble in ordinary solvents. By evaporation of the benzene, a mass of resinous material was obtained indicating complete oxidation of the rubber. From this mass these substances were obtained: a viscous fluid, to which the formula $\mathrm{C}_{10} \mathrm{H}_{18} \mathrm{O}$ is assigned; a yellow spongy solid, corresponding to $\mathrm{C}_{10} \mathrm{H}_{13} \mathrm{O}_{3}$; a hard, brittle body resembling shellac, and also corresponding to $\mathrm{C}_{10} \mathrm{H}_{16} \mathrm{O}_{3}$. 
These last two substances resemble Spiller's resin. - Ditmar, (Gummiztg., 20, 579, (1906)), vulcanized Guayule rubber with io percent sulphur, and chalk varying in amount. In one set of experiments the rubber and all ingredients were thoroughly dried; in another set the rubber was used in its natural condition, carrying 14.5 percent. of moisture. The strength in each sample increased with the quantity of chalk, up to 40 percent. but the stretch reached a maximum at 16 percent. chalk for the dry rubber; with the natural damp rubber, two points of maximum stretch were found,-one with 16 percent. chalk and the other with 24 percent. The chalk is thought to form a colloid substance with the rubber, and is also supposed to prevent porosity in the vulcanized rubber by uniting in some way with the moisture.-Ditmar, (Ibid., 628), assuming that the deterioration of rubber is caused by oxidation, forming resins, such as Spiller's resin and the substances above mentioned by Herbst, has proposed to test rubber goods for durability as follows:- The sample, in thin sheet, is dried in vacuo over calcium chloride, or at $100^{\circ}$ till the weight is constant. About $0.5 \mathrm{gm}$. is then sealed in a glass tube with oxygen (or in a $\mathrm{U}$-tube connected with an oxygen tank under low pressure, and heated in a water-bath), and heated to $100^{\circ}$ for several hours. After cooling, the rubber is quickly weighed and the increase in weight is assumed to be a measure of the readiness with which the rubber is oxidized. A good rubber, after five hours heating should not gain over 4 percent. Some samples actually lose weight under the test, due to the oxidation of free sulphur, but such rubbers are probably porous. -Ditmar, (Ibid., 9I8), has vulcanized eighteen varieties of rubber containing different amounts of resin, using Io percent. sulphur, and several atmospheres pressure, for one hour at $145^{\circ}$. Those rubbers containing seven percent. or over, of resin were completely vulcanized, and some with less resin were much under-cured. Several of those with high resin content were very elastic and strong after vulcanizing. The author holds that the resin content has less effect than the origin and character of the rubber, upon the curing. The same writer tested balata in a similar way, but with increasing proportion of sulphur. The maximum stretch and strength were obtained with 35 to 40 percent. of sulphur. Longer vulcanizing with more sulphur, increased the stretch but lowered the breaking strength.-The author, (Ibial, 20, 999, (1906)), has further studied the effects of resin in vulcanizing rubber. The strength decreased as the resin content increased, and the rubber showed a tendency to become softer. It is concluded that atmospheric oxidation is much promoted as the resin content is higher. The same writer, (Ibid., I026), has reviewed the theories of Weber and others on the vulcanization process, and shows that they may be harmonized with the new formula proposed by Harries, (Ber., 38, I I95, (I905)).-Ditmar, (16id., 394), has examined various crude rubbers to ascertain the resin content. There seems to be considerable variation in the several commercial grades, ranging from about I2 percent. in some of the African rubbers, down to 0.57 percent. in a fine Para rubber. The resin content is much influenced by the method of drying the sample before extraction. A fine Para, dried in zacuo, over calcium chloride, showed $\mathrm{I} .44$ percent. in the acetone extract; but dried at $80^{\circ}$, in a hot water oven, the percentage of resin was raised to 6.83 . The author also examined the effect of sulphur on the tensile strength of the rubber after 
vulcanizing:-Using a good Para rubber, having 6.27 percent. resin, various percentages of sulphur from 5 to 40 , were added and the test piece vulcanized at $145^{\circ}$, under $4-5$ atmospheres pressure. On testing the strength and elongation, from 20 to 40 percent. of sulphur, gave the best results. The author also finds Torrey's method of determining caoutchouc is useless for practical purposes.-Harries, (Ber., 38, 3985, (I905)), has applied his ozone process for the study of the constituents of caoutchouc, to an examination of the hydrocarbons of gutta-percha, with a view to determining the relation between these substances in the two materials. Gutta-percha yields a diozonide, $\mathrm{C}_{10} \mathrm{H}_{16} \mathrm{O}_{6}$, having the same molecular weight, and reacting in the same way, as that obtained from caoutchouc, but the proportions of aldehyde to acid, yielded by hydrolysis, are reversed in the two cases, and the view is held that the molecules split up in different ways, owing to isomerism in the ozonides. And it is thought that the original hydrocarbons may be stereochemical isomers.-Tilden, (Chem. New', 94, 102, ( I906)), has examined the latex of Dyera costulata from which the commercial pontianak is said to be produced. The creamy liquid was miscible with water, but was coagulated by acids, strong brine, or hot solutions of sodium carbonate. It furnished about 44 percent. of solid material when coagulated by hydrochloric acid; this material is nearly all soluble in alcohol or acetone. A little caoutchouc is present, with a crystallizable substance having a melting point of $173^{\circ}$, and soluble in alcohol, - Marckwald and Frank, (Gummiztg., 20, I254, (Igo6)), have analyzed crude rubber obtained from cultivated Ficus elastica, grown in Palermo and found it contained:-moisture, (at $100^{\circ}$ ), I.5I ; organic dirt, 2.30; sand and inorganic dirt, I.75; resin, 22.19; rubber, 72.29 percent. The resin is higher than from crude rubber from the same plants grown in the tropics.

Sanitation and Health:-Erdmann and Vahlen, (Arch. Pathol. $u$. Pharm., 53, 401 ; Chem. Centr., 1905, 2, 1805), note the injury to the health of work people making $p$-phenylenediamine, and attribute this to the oxidation products, especially quinone-diimine, $\mathrm{NH}: \mathrm{C}_{6} \mathrm{H}_{4}: \mathrm{NH}$. As $p$-phenylenediamine is much used for dyeing hair and furs, the suggestion is made that its use for human hair be prohibited.-Latham, (Electrician, $56,398)$, reports a case of lead poisoning caused by electrolysis of the service pipe which supplied the water for a dwelling house. Leakage from the mains of an electric lighting system was the cause of the electrolysis.-Dibdin, (J. Soc. Chem. Ind., 25, 4I4, (Igo6)), reports the results of experiments conducted by the corporation of Devizes with primary sewage filter beds, one fitted with horizontal layers of slate some 2 or 3 inches apart, and the other filled with coke breeze. The latter bed had twice the capacity of the former. Sewage, unscreened and unsettled, was run on these beds and an effluent obtained directly suitable for final treatment on the fine beds. No nuisance from sludge resulted. A small amount of black matter flowed from the slate bed, which dried to a black "humus," without odor. Tables of analysis were given from 3 series of tests made. Slate beds divicled by distance pieces, are on trial at Trowbridge and High Wycombe with satisfactory results in eliminating sludge. The effluent is then further treated on contact beds, sprinkler beds, or on land. The operation is inoffensive, the suspended solid matter being decomposed by aerobic bacterial action.-Blyth, (Analyst., 3 I, I 50, (I906)), 
has tested the efficacy of various phenolic disinfectants when in the presence of organic matter. The germicidal effect is much reduced in the case of the higher phenols, but the phenol itself seems to lose less of its value. The poisonous character of these substances seems to decrease as the number of hydroxyl groups in the structure increases and is proportional to the germicidal value. Tests were made with phenol, cresols. resorcinol, pyrogallol, "Izal," and "Cyllin," on worms of equal weight. and the time noted which elapsed before death. Phenol and cresols mixed with milk were very active poisons, while Izal and Cyllin were weak in toxic effect. The germicidal character of the former was little reduced by the admixture with the milk, but the latter lost 80 percent. of its value.According to an article in the London Times of Nov. I, Igo6, a government investigation of diseases due to industrial occupation, is about to be made. A committee has been appointed to study the question, and has announced what lines of investigation are to be followed:-Slow poisoning, due to fumes of certain liquids (carbon disulphide, aniline, etc..), and gases (carbon monoxide, hydrogen sulphide, nitrous fumes, etc..), dust (basic slag, metallic particles, coal, etc.,), ulcers and slin diseases (chrome), glanders, and various other diseases. Lead, mercury, arsenic and phosphorus poisoning, and anthrax, have already been made subjects of legislation and will not be included.-Schneider, (Chem. Centr. I, I897. ( I906)), has found that substitution in the cresols, by the sulphonic acid groups, especially in the ortho position, increases the disinfecting property of the product. Aqueous solutions of cresols which contain hydrochloric or sulphuric acids, are more effective disinfectants. Soaps containing cresols should not contain free caustic alkali, since this decreases the disinfecting power, by forming alkali compounds which have little disinfecting power.

Salts, Alkali, Etc.-Grossmann, (J. Soc. Chem. Ind., 25, 4I I, (Igo6)), describes his improved method of making anmonium sulphate from gas liquors, whereby noxious efftuents are avoided. The liquor is distilled by steam, but without adding lime or alkali. This separates the free ammonia and volatile salts. The waste liquor, containing the fixed salts, tar oils and phenols, is in large part cooled and returned to the scrubbers to be used over again and thus becones richer in fixed ammonium salts. The smaller portion of the liquor withdrawn each 24 hours must contain such an amount of fixed salts as will be equal to the total production of such fixed salts, in that period. The liquor is evaporated to small bulk by waste heat of the colke-ovens, or the use of breeze in a gas works. On cooling, ammonium chloride crystallizes, while the liquor contains thiosulphate, chloricle and thiocyanate of ammonium. This is put in a still and dilute sulphuric acid added. On agitating and heating to $100^{\circ}$, part of the thiocyanate is decomposed and the rest distils as such. The gases pass a tower charged with limestone, and a solution of calcium thiocyanate is obtained; the tnabsorbed gases next pass through iron oxide purifiers, or a mixture of iron salt with alkali, whereby hydrogen sulphide and volatile cyanogen compounds are absorbed. The waste liquor from this still contains ammonium sulphate and chloride, and free sulphuric acid, and is used to dilute the sulphuric acid in the absorbers for the ammonium sulphate. The hydrochloric acid set free here is absorbed in water. To recover cyanides and ferrocyanides when present in large quantity, fer- 
rous or zinc sulphate is added to the evaporated liquor and, on careful neutralization with sulphuric acid, insoluble ferro- or zinc ferro-cyanides precipitate and are filtered out. If in small amount, these ferro-cyanides are decomposed by the sulphuric acid, and the hydrocyanic acid evolved is absorbed in the iron oxide or alkaline iron salts. The chief object of the process is to meet sanitary conditions, rather than a saving in manufacture.-Gutbier and Bünz, ( $Z$. anorg. Chem., 48, I62, (I906)), have examined the bodies produced by the action of chlorine on bismuth salts in the presence of potassium hydroxide. These substances could not be identified as chemical compounds, as they could not be made of uniform composition. The concentration of the alkali has much effect on the product. In a second article, (I bid., 294), the authors dispute the correctness of Deichler's formula, (Z. Elektrochem., 5, 517, (1899)), for potassium bismuthate, $\mathrm{KBiO}_{3}$, which is formed by electrolyzing a solution containing potassium hydroxide, bismuth oxide and potassium chloride. The product is a mixture which yields peroxides of bismuth when treated with nitric acid.-Green, (J. Soc. Dyers Colorists, 22, 9, (1906)), has an interesting review of the work of Bernthsen, Bazlen, Reinking, Dehnel, and Labhard, in a controversy with Baumann, Thesmar and Fossard, upon the constitution of hydrosulphides. The conclusion reached

is that sodium hydrosulphide is an auhydride salt, ${ }_{\mathrm{SO}-\mathrm{ONa}}^{\mathrm{S}-\mathrm{ONa}}$

Portisch, (Stahl. u. Eisen, 26, 93), describes with illustrations the method of building loam molds for casting caustic pots. The metal must be free from any slag or cinder, lest inequalities in the surface be produced, which furnish points of attack by the fused caustic on the iron.-Wallis, ( $A \mathrm{mn}$., 345, 353. (Igo6)), holds that cyanogen is not produced in the electric arc by direct union of carbon with nitrogen, but rather by decomposition. of hydrocyanic acid, which is formed from the hydrogen of water vapor and nitrogen. A method for detecting and estimating cyanogen in the presence of hydrocyanic acid is also given.-Frederich, Mallet and Guye, (Mon. sci., 20, 5I4, (I906)), have prepared lead peroxide by mixing lead sulphate with magnesia, and suspending the mass in water with vigorous agitation, while passing in chlorine gas. The operation is best carried on in a rotating barrel, or chlorination apparatus. The crude product contained about 90 percent. lead peroxide, which was raised to 97 percent. by treating with caustic soda and acid, successively.-The Fortysecond Annual Report by the Chief Inspector of Alkali Works for the year 1905, was issued in May, 1906. This shows some increase in the number of works producing ammonium salts, but in other lines, there is little change. A difficulty in absorbjng chlorine passing from the exit flues of bleach chambers, was overcome by adding pipe-columns, fed with caustic soda solution, in the absorption plant. A revival of activity in the Le Blanc process is noted, and some acidity in the chimney gases was detected. The residual gases from the Claus kiln continue to give trouble, and Hemingway's proposal to use ferrous sulphite as absorbent, was carefully tested, but the results were unsatisfactory. Mechanical draught from the boiling juice and which attacks the clean copper tubes of the pan for sulphuric acid chambers is very satisfactory. Atomized water, in place of steam for supplying the chambers, has not proved altogether suc- 
cessful in the last chambers of the system, owing to its effect on the temperature. In concentrating, the Kessler apparatus continues to give satisfaction. No additional plants using "contact" processes have started during the year, but some improvement in the process is noted, and there is less acidity in the residual gases. Some trouble was experienced with the effluent from ammonia works, as it contained sulphocyanides, which were thought to retard bacterial action in the filter beds. The removal of the sulphocyanides from the gases by iron oxide, avoids trouble with the effuent. Ammonium cyanide in gas-liquor produces hydrocyanic acid in the gases from the ammonia saturator, which must be removed before the oxide of iron purification, or passage into the Claus kiln. The ammonium cyanide can be removed by passing the gas into polysulphides. The effects of hydrocyanic acid upon the blood have been studied and the view advanced that a compound with hemoglobin is produced. The production of ammonium sulphate is increasing, owing to the starting of producer gas plants with ammonia recovery. The formation of "blue salt" in the ammonia saturators was noted in several cases, and was attributed to the ferrous ferrocyanide produced from ammonium ferrocyanide and iron. The ammonium ferrocyanide probably forms in the saturator by action of the ammonium cyanide on ferrous sulphide, produced in the saturator by insufficient acid supply. One case of "blue salt" formation was traced directly to the presence of an iron stay rod in the saturator, being dissolved by the acid, thus forming ferrous sulphate in quantity. At another time, an insufficient mixing of ammonia gas, with the acid in the saturator, led to the "blue salt" formation. Mond gas for salt evaporation gives good results. Mechanical evaporators are being tried. White arsenic has largely increased in production, for the most part, from tin ores. Rotary kilns for cement are also increasing in number. The shale-oil industry of Scotland shows some considerable increase over the preceding year. Boeke, (Z. anorg. Chem., 50, 244, (I906)), has re-investigated the opposing statements of Finkenstein and Le Chatelier relative to the fusion of barium carbonate. The former puts the melting point above $135^{\circ}$; the latter at $795^{\circ}$. This author attributes the differences to the different conditions of the work of the two experimenters. In a current of carbon dioxide, he finds the fusion point to be $\mathrm{I} 380^{\circ}$, but heated in an open crucible, carbon dioxide is expelled and fusion follows at $900^{\circ}$. - Grossmann, (Chem. Ztg., 30, 907, (I906)), finds that titanium chloride yields a black precipitate with potassium cyanide, which, on heating, passes into titanic acid. Thus, double cyanides of the formula, $\mathrm{R}_{3} \mathrm{Ti}(\mathrm{CN})_{0}$, do not exist. With potassium ferrocyanide, a brownish red precipitate, passing into a yellow-orange color, is formed; the ferricyanide gives a brown precipitate, changing to green; sodium acetate produces a dark green color in the solution, and, on heating, precipitates a basic acetate. Acetic and formic acids do not react, but oxalic acid gives a brown precipitate in the presence of alcohol. Gallic, salicylic and succinic acids cause colored precipitates, and tartaric and citric acids, with sodium hydroxide produce a blue solution.

Sugar:-Claassen, (Z. Ver. Zuckerind., I906, 260), advises the return of drainage washings and press-waters to the diffusion battery, thus preventing nuisance by their fermentation, and recovering a slight amount of sugar. These liquors being already charged with non-sugars, dissolve less of these undesirable substances from the fresh charge, and so leave 
more of these bodies in the press-cake. These waste liquors should all be mixed and added to the diffusion with fresh water. -Néumann, ( $Z$. Zuckerind., 30, 477, (1906); J. Soc. Chem. Ind., 25, 705, (I906)), has tried the sodium bisulphite formaldehyde and sodium sulphoxylate formaldehyde, for decolorizing beet juice, with good results. Twenty hectoliters of thick juice were decolorized by one-half liter of a solution of the compound of $1.26 \mathrm{sp}$. gr. No invert sugar is formed.- Halousek, (Ibid., 479), reports similar results from a sugar factory at Radotin, and claims better clarification than with sulphur. - Mandelik, (Ibid., 480), finds this preparation has better decolorizing effects than has aluminum sulphite. -Bulow, (Z.Ver. Zuckerind., 6or, (1906)), found copper in the mud from the thick juice filter, following the washing of the evaporating pan with sodium carbonate and hydrochloric acid. $\mathrm{He}$ also found that polished brass was attacked by thin juice and copper dissolved. This is attributed to the action of ammonia which is evolved from the boiling juice and which attacks the clean copper tubes of the pan. After the tubes become scaled with lime, this attack on the metal ceases. The largest quantity of copper was always found on Monday following the regular Sunday cleaning of the evaporator.

Glue:-Trotman and Hackford, (J. Soc. Chem. Ind., 25, I04, (Ig06)), have studied the conditions affecting foaming and consistency of glue. Consistency is very much affected by the presence of peptones and as over-boiling causes peptonization, it is equally responsible for loss of consistency, and also increases the foaming property of glue. Consistency was measured by noting the time for symmetrical spheres to fall through a column of the glue under test; foaming was tested by shaking $25 \mathrm{cc}$. of glue solution in a tube $70 \mathrm{~cm}$. long and of such diameter that $\mathrm{I} \mathrm{cm}$. length of the tube has a volume of I cc. The solution is warmed to $60^{\circ}$, by surrounding the tube with a water jacket at $60^{\circ}$. The top of the foam is read off, and is found to be constant, with constant temperature. But as the foam produced varies with the temperature, this constancy of temperature is very important. Rising temperature decreases the foam, as both the viscosity and surface tension become less. The height of foam is approximately proportional to the height of the liquid in the tube. Peptones in small amount, increase the foam figure to an especially marked degree, but have little effect on the consistency so long as they do not replace albumose nitrogen; but by replacing the gelatin with peptone, the consistency rapidly falls. Alkalies, especially sodium, increase the foam; soap at first decreases it, but above a certain amount, increases the foam. Acids cause hydrolysis and peptone formation, with resulting fall of consistency. Suspended matter increases foam, while salts in large quantity, cause hydrolysis. - Watson, (Ibid., 209), enumerates certain causes of foaming in glue:-(I). Alkali, by saponifying any grease, or by aiding the formation of gelatone. (2). Sulphurous acid. (Boric and other acids probably have little effect). (3). Long heating, causing hydrolysis of the gelatin to form gelatone, which is analogous to peptone. (4). Mucin substances not removed from the raw material before extraction of the glue.

Tanning:-Procter and Bennett, ( $J$. Soc. Chem. Ind., 25, 25I, (Igo6)), have investigated the barium and calcium salts of gallic, protocatechuic and digallic acids. The work was undertaken to test the reliability of the figures obtained for the "Total Absorptive Value," by the Parker-Payne method of analysis for tannins. Some tannic and gallic acids in alkaline 
solution are easily oxidized and as the products are thought to be of probable acid character, these may affect the apparent quantity of alkali used for neutralization. Thus in the open filtration of the Parker-Payne method lies a probable source of error. The author used various ways to prevent oxidation and then tested the solubility and completeness of precipitation of the barium salts of the above acids. The results showed that precipitation was in every case incomplete, even with the addition of alcohol. Similar results were obtained with lime. The authors conclude that the original Parker-Payne method is unreliable. They also decline to accept the assumption of Parker and Payne that "the majority of tanning materials depend upon the anhydrous digallic acid content for their activity as tanning agents." - Procter and McCandlish, (J. Soc. Chem. Ind., 25, 254, (I906)), have devised a method for determining ammonia in old lime liquors, by which the time of the analysis is much shortened and the decomposition of nitrogenous matter in the liquor during the extraction of the liquor is avoided. - Paessler, (Colleginm, I906, I35, I42), has tested a new tannin source, wiz., the bark of the barbatimao tree, a South Annerican plant. The bark yielded 27 percent. tannins and 4 percent. non-tannins. It gave a soft, bright colored leather with fine grain, firm, yet pliable. - Kopecky, (Ibid., 97, IOI, IIO, I I 7, I25), has a series of articles on chromed hide powder and its use in tamnin analysis. - Paessler, (Deutsch. Gerber Ztg., I905, I39; J. Soc. Chem. Ind., 25, 83), reports upon a new tanning material, (Kanatchil bark), from the Ladrone Islands. It contains, of tannin absorbed by hide, 29.3; non-tannin, 5.6 ; insoluble, 52.I ; water, I3.o percent. About 23 percent. of the tannin is easily soluble, but the non-tannins are lower than in oak or hemlock bark; it is suggested that this material be used with oak and hemlock. It forms light-colored leather and has noticeable weight-giving properties. - Beck$\mathrm{er}$, in a report to the International Association of Leather Trades Chemists, at the Frankfort meeting, discusses the poisonous character of chromium salts and chromates. Very few cases of serious poisoning could be found; but the workmen often stuffer from sores on the hands, especially when neglected. Rubber gloves, and free use of vaselin, are recommended. There is nothing to fear from the leather, as chromium oxide is not a poison. Rogers, (J. Soc. Chem. Ind., 25, IO3, (Ig06)), has described the Oakes process of bating skins by a fermentation with glucose, sulpht1r and yeast. There is no putrefactive action and no loss of hide substance, but the lime is thoroughly removed and the skin left soft and open. The action is rapid, as a heavy cow-hicle can be de-limed in eight hours, and no subsequent drench or pickle is needed. -Dekker, (Ber., 39, 2497 . (1906)), questions the correctness of the digallic acid formula proposed by Schiff for tannin, as it does not explain certain of the known properties of tannin. The author advances five or more properties and reactions of tannin which should be capable of explanation by its structural formula, and then proposes the following:-

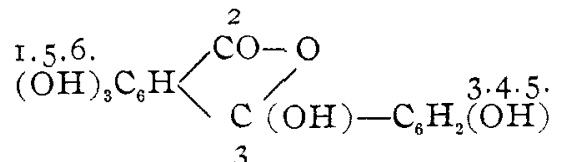

-Fahrion, (Colleginm, I906, 286), discusses the theory of leather forma- 
tion with vegetable tannins, in view of the suggestion of Lumiere and Seyewetz that oxygen is essential to the rendering of the gelatin completely insoluble. The author holds that the tannins first produce oxidation products, similar to peroxides, and these yield oxygen to the skin. Sumac is presumed to contain a large quantity of the oxidized tannin, and hence does not show further oxidation. Its oxygen content is about 44 percent, while oak tannin has only 36 percent.

Textiles:-Thomson, (J. Soc. Chem. Ind., 25, 157, (I906)), has investigated the iron stains produced on cloth when the warp stands over night in the loom. The reeds are rusted and this causes a streak in the finished goods. This rusting is attributed to chlorates in the zinc chloride of the size. The chloride being made from the dross of galvanizing operations by solution in hydrochloric acid, sodium chlorate is added to oxidize the iron and any excess left in the size, causes rapid rusting of the iron. Bleaching powder, Weldon mud, permanganates, chromic acid, sodium peroxide and hydrogen peroxide may all be used to oxidize the iron, but the last must all be removed from the warp, or rapid rusting of the reeds will take place. -Vignor and Mollard, (Compt. rend., I42, I343, (1906)), have investigated the effect of chlorine on wool. There is loss of weight which may amount to Io percent; there is some loss of elasticity and shrinkage is diminished, but the felting property is not much lessened. After treatment with chlorine, wool dyes deeper and more brilliant shades than before.

Miscellaneous:-Paton, (J. Soc. Chem. Ind., 25, 6, (Igo6)),. discusses Profit in Industrial Enterprise. The essentials for successful manufacturing are pointed out, and numerous common mistakes are instanced. Pretentious plants frequently earn no profit for the stockholder, and even run at a loss. English methods are the result of conditions in that country and should not be disparaged too strongly. Distribution is the most important consideration in most industries; sure sales at fair prices are as necessary as economy and efficiency in production. The commercial department will determine the future of many large industries. A plea for commercial, as well as technical education is made. The practice of demanding a guarantee for new processes and machinery, is leading to abuses and carelessness on the part of the users. Bad legislation often injures business and rash experiments are sometimes made. Methods of determining cost are frequently faulty, while depreciation of plant must be reckoned in determining profits. - Smith, (Ibid., 54), reviews the history of dust explosions in coal mines, flour mills and other industries, with special reference to the reduction of danger in flour mills, through the introduction of the "roller process" and use of separators, such as the "Cyclone" and others. - Garry, (Ibid., 359), has contributed a paper on the "Depreciation of Plant and Machinery,"-a subject of special interest to the chemical manufacturer. The annual charge for depreciation is considered under (I) Deterioration, (2) Renewals, (3) Obsolescence, as affecting (a), the cost of production, (b), income tax, (c), fire insurance. -Royle, (Ibid., 452), reviews the methods of water softening with particular reference to the apparatus and process of Messrs. Reisert, in which barium carbonate is used with lime, to remove sulphates and hardness. - Hart, (Ibid., 456), reports instances in which perforations of sheet lead by insects, have occtrred. The insects were of the wood-boring 
variety and were identified as Sirex Gigas. The damage consisted of small holes through the bottom of a new sulphuric acid chamber. It was proposed to coat the timbers before covering with lead, with a thick mixture of gas-tar and creosote oil.-Conroy, (Ibid., IOII), reviews the chemical trade of England as compared with that of Germany. The conclusions arrived at, are that as regards general chemicals and medicines, England's position is satisfactory, and that she holds her own as to volume of trade. But there appears evidence of a lag behind the times; the trade in fine chemicals, organic and inorganic and synthetic alkaloids. perfumes, etc., is not adequately represented in England. Many tables of imports and exports of Germany and the United Kingdom, are given. Thorne and Jeffers, (Analyst., 3I, IOI), have devised a method for purifying zinc from arsenic. The zinc is fused and treated with sodium,-about I gram per pound of zinc. The mixture is well mixed by pouring from one crucible into another, and then heated to just above the melting point of zinc, with exclusion of air, at first, and later with the crucible open. A crust forms, which is broken through and the metal poured off and heated considerably above its melting point, and after skimming, it is granulated. Arsenic can be removed from hydrochloric acid by the use of a copper-tin couple. -Baxter, (Eng. Pat. 5,209, (1905)), proposes to impregnate wood, textile fabrics, paper or other material, with a solution containing ammonium phosphate and boric acid, to render them less combustible and more resistent to water.

\section{REVIEW OF INORGANIC CHEMISTRY.}

JAS. LEWIS HOWE.

Received January 3, I907.

In this review the order of the Periodic System will be followed. Material which has already been treated in the Review of American Chemical Research in this Journal will be omitted, as well as most of the phenomena of radioactivity.

Group I. A new determination of the boiling points of the metals of the alkalies has been made by Ruff and Johannsen (Ber., 38, 360I), not less than 25 grams of each metal being boiled in a wrought iron retort, and the temperature measured by a platinum-platinum-rhodium thermoelement. Experiment showed that at the temperatures used, the metals did not attack the iron vessels. The results were: cesium, $670^{\circ}$; rubidium, $696^{\circ}$; potassium, $757.5^{\circ}$; sodium, $877.5^{\circ}$. Lithium did not volatilize at the temperature at which the retort melted, so that its boiling point is at least above $1400^{\circ}$. No simple mathematical formtila could be found to express the boiling points as a function of the atomic weight. The lithium used in the experiments was prepared by the electrolysis of a mixture of lithium and potassium chlorides, but the same authors find $(Z$. Elektrochem., I2, I86) a better electrolyte in a mixture of lithium bromide with IO-I 5 per cent. lithium chloride. In a graphite retort with a thick iron wire as kathode and a current of Ioo amperes at Io volts the output is 80 per cent. of the theoretical. The metal obtained contained only a trace of sodium as impurity, and fused at $180^{\circ}$.

It has been found by Hofmann and Hiendlmaier (Ber., 39, 3I84) that the burning of potassium to $\mathrm{K}_{2} \mathrm{O}_{4}$ is a powerful oxidizing agency. Most 